\title{
The Cardiovascular Therapeutic Potential of Propolis-A Comprehensive Review
}

\author{
Henrique Silva ${ }^{1,2, *(\mathbb{D}}$, Rafaela Francisco ${ }^{3}$, Ariana Saraiva ${ }^{4}$, Simone Francisco ${ }^{5}$, Conrado Carrascosa 4 \\ and António Raposo 6,*(D)
}

1 Informetrics Research Group, Ton Duc Thang University, Ho Chi Minh City 758307, Vietnam

2 Faculty of Pharmacy, Ton Duc Thang University, Ho Chi Minh City 758307, Vietnam

3 Pharmacological Sciences Department, Faculty of Pharmacy, Universidade de Lisboa, Av Prof Gama Pinto, 1649-003 Lisboa, Portugal; rafaelafrancisco@campus.ul.pt

4 Department of Animal Pathology and Production, Bromatology and Food Technology, Faculty of Veterinary, Universidad de Las Palmas de Gran Canaria, Trasmontaña s/n, 35413 Arucas, Spain; ariana_23@outlook.pt (A.S.); conrado.carrascosa@ulpgc.es (C.C.)

5 Faculty of Medicine, Nutrition Lab-Universidade de Lisboa, 1649-028 Lisboa, Portugal; on1948@onutricionistas.pt

6 CBIOS (Research Center for Biosciences and Health Technologies), Universidade Lusófona de Humanidades e Tecnologias, Campo Grande 376, 1749-024 Lisboa, Portugal

* Correspondence: henriquesilva@tdtu.edu.vn (H.S.); antonio.raposo@ulusofona.pt (A.R.)

Citation: Silva, H.; Francisco, R.; Saraiva, A.; Francisco, S.; Carrascosa, C.; Raposo, A. The Cardiovascular Therapeutic Potential of Propolis-A Comprehensive Review. Biology 2021, 10, 27. https://doi.org/10.3390/ biology10010027

Received: 7 December 2020 Accepted: 29 December 2020 Published: 4 January 2021

Publisher's Note: MDPI stays neutral with regard to jurisdictional clai$\mathrm{ms}$ in published maps and institutional affiliations.

Copyright: (C) 2021 by the authors. Licensee MDPI, Basel, Switzerland. This article is an open access article distributed under the terms and conditions of the Creative Commons Attribution (CC BY) license (https:// creativecommons.org/licenses/by/ $4.0 /)$.
Simple Summary: Propolis, also described as bee glue, is a natural component made up of a resinous mixture of honeybee compounds from multiple botanical sources. The literature has demonstrated a variety of medicinal properties attributed to propolis due to its chemical complexity. However, the positive effects of propolis on cardiovascular health have gained little coverage. Therefore, we aimed to provide an accurate and up-to-date review of the main cardiovascular health benefits of propolis. In particular, we intend to establish the key varieties of propolis and pharmacological compounds with the therapeutic effects that are most encouraging, as well as the physiological processes by which those advantages are accomplished. The Brazilian green and red varieties reveal the greatest number of beneficial activities among the varieties of propolis studied. While much of the cardiovascular beneficial effects appear to derive from the cumulative actions of several compounds working via multiple signaling mechanisms, some individual compounds that may enhance the existing therapeutic arsenal have also shown significant results. It is also worth exploring the prospect of using propolis as food supplements.

Abstract: Owing to its chemical richness, propolis has a myriad of therapeutic properties. To the authors' knowledge, this is the first comprehensive review paper on propolis to focus exclusively on its major effects for cardiovascular health. The propolis compound varieties with the most promising therapeutic benefits and their respective physiological mechanisms will be discussed. Propolis displays an anti-atherosclerotic activity, attained through modulation of the plasma lipid profile and through stabilization of the fatty plaque by inhibiting macrophage apoptosis, vascular smooth muscle proliferation and metalloproteinase activity. The antihypertensive effects of propolis probably arise through the combination of several mechanisms, including the suppression of catecholamine synthesis, stimulation of endothelium-dependent vasorelaxation and vascular anti-inflammatory activity. The anti-hemostatic activity of propolis is attributed to the inhibition of platelet plug formation and antifibrinolytic activity. By inhibiting the secretion of proangiogenic factors, propolis suppresses endothelial cell migration and tubulogenesis, exerting antiangiogenic activity. The antioxidant and anti-inflammatory activities are responsible for protection against vascular endothelial and cardiomyocyte dysfunction, mostly by the prevention of oxidative stress. Among the reviewed propolis varieties, the Brazilian green and red varieties show the largest number of beneficial activities. Further research, especially preclinical, should be conducted to assess the cardiovascular benefits of the given varieties with different compositions. 
Keywords: propolis; antihypertensive; antiangiogenic; antioxidant; cardiovascular protection

\section{Introduction}

This paper intends to provide an objective and up-to-date comprehensive review on propolis. To the authors' knowledge, this is the first paper to focus exclusively on its cardiovascular effects, covering more subjects than the most recently published reviews [1,2]. Propolis, also known as bee glue, is a natural product consisting of a resinous mixture of substances collected by honeybees (Apis mellifera L.) from different botanical sources, beeswax and salivary enzymes. "Propolis" is a Greek word meaning "defense of the city", which alludes to the fact that honeybees use propolis as a sealant material. At the beehive entrance, propolis traps predators, being used also to fill in the beehive cracks and as a thermal isolator, therefore maintaining the hive in perfect health $[3,4]$. From a physicochemical standpoint, propolis is a lipophilic material, hard and breakable when cold but soft and very sticky when warm. It has a pleasant aromatic smell and a variable coloration, which depends on its botanical source, age and geographical climate, ranging from cream, green or red to brown $[4,5]$. Table 1 summarizes the main propolis geographic origins and their major constituents.

Table 1. Origins and major constituents of propolis (adapted from [6-8]).

\begin{tabular}{|c|c|c|}
\hline Authors & Geographical Origin & Major Constituents \\
\hline $\begin{array}{c}\text { Piccinelli et al. (2013) [9]; Soltani } \\
\text { et al. (2017) [10] }\end{array}$ & Algeria & Diterpenes \\
\hline $\begin{array}{l}\text { Salas et al. (2016) [11]; Fangio } \\
\text { et al. (2019) [12] }\end{array}$ & Argentina & $\begin{array}{l}\text { Sesquiterpenes, flavonoids, } \\
\text { phenolic acids }\end{array}$ \\
\hline $\begin{array}{c}\text { Huang et al. (2014) [13]; } \\
\text { Silva-Carvalho et al. (2015) [4] }\end{array}$ & Australia & $\begin{array}{l}\text { Stilbenes, phenylpropanoids, } \\
\text { flavonoid esters }\end{array}$ \\
\hline $\begin{array}{l}\text { Trusheva (2006) [14]; Alencar et al. } \\
\text { (2007) [15]; Silva et al. (2008) [16]; } \\
\text { Righi et al. (2011) [17] }\end{array}$ & Brazil (red) & $\begin{array}{l}\text { Triterpenoids, isoflavonoids, } \\
\text { prenylated benzophenones }\end{array}$ \\
\hline $\begin{array}{c}\text { Paviani et al. (2013) [18]; Quintino } \\
\text { et al. (2020) [19] }\end{array}$ & Brazil (green) & $\begin{array}{l}\text { Triterpenoids, flavonoids, } \\
\text { phenolic acids }\end{array}$ \\
\hline $\begin{array}{l}\text { da Silveira et al. (2016) [20]; } \\
\text { Machado et al. (2016) [21] }\end{array}$ & Brazil (yellow) & Triterpenoids \\
\hline $\begin{array}{c}\text { Fernandes et al. (2015) [22]; Lima } \\
\text { et al. (2019) [23] }\end{array}$ & Brazil (brown) & $\begin{array}{l}\text { Sesquiterpene, flavonoids, } \\
\text { phenolic acids }\end{array}$ \\
\hline \multirow{2}{*}{ Papachroni et al. (2015) [24] } & Cameroon & \multirow{2}{*}{ Triterpenoids } \\
\hline & Congo & \\
\hline $\begin{array}{l}\text { Montenegro et al. (2001) [25]; } \\
\text { Muñoz et al. (2001) [26]; }\end{array}$ & Chile & $\begin{array}{l}\text { Benzophenones, flavonoids, } \\
\text { diterpenes }\end{array}$ \\
\hline $\begin{array}{l}\text { Silva-Carvalho et al. (2015) [4]; } \\
\text { Miguel and Antunes (2011) [27] }\end{array}$ & China & Flavonoids \\
\hline Graikou et al. (2016) [28] & Croatia & Diterpenes \\
\hline Bankova (2005) [29] & Cuba & $\begin{array}{l}\text { Polyisoprenylated } \\
\text { benzophenones }\end{array}$ \\
\hline Graikou et al. (2016) [28] & Cyprus & Diterpenes \\
\hline Hegazi et al. (2002) [30] & Egypt & Di- and triterpenes \\
\hline Rushdi et al. (2014) [31] & Ethiopia & Triterpenoids \\
\hline
\end{tabular}


Table 1. Cont.

\begin{tabular}{|c|c|c|}
\hline Authors & Geographical Origin & Major Constituents \\
\hline $\begin{array}{l}\text { Velikova et al. (2000) [32]; } \\
\text { Bankova et al. (2002) [33]; Melliou } \\
\text { and Chinou (2004) [34]; }\end{array}$ & Italy & $\begin{array}{l}\text { Diterpenic and phenolic } \\
\text { compounds }\end{array}$ \\
\hline $\begin{array}{l}\text { Huang et al. (2014) [13]; } \\
\text { Silva-Carvalho et al. (2015) [4] }\end{array}$ & Iran & $\begin{array}{l}\text { Monoterpenes, diterpenes, } \\
\text { sesquiterpenes, coumarins }\end{array}$ \\
\hline $\begin{array}{l}\text { Banksota et al. (2001) [35]; Huang } \\
\text { et al. (2014) [13] }\end{array}$ & Japan & Prenylated flavanones \\
\hline $\begin{array}{c}\text { Petrova et al. (2010) [36]; Popova } \\
\text { et al. (2011) [37] }\end{array}$ & Kenya & Triterpenoids \\
\hline $\begin{array}{l}\text { Huang et al. (2014) [13]; Toreti } \\
\text { et al. (2013) [38]; Silva-Carvalho } \\
\text { et al. (2015) [4] }\end{array}$ & Korea & Lignans \\
\hline $\begin{array}{l}\text { Siheri et al. (2016) [39]; Siheri et al. } \\
\text { (2014) [40] }\end{array}$ & Lybia & Diterpenes \\
\hline Popova et al. (2011) [37] & Malta & \\
\hline Martinotti (2015) [41] & Mexico & Prenylated benzophenones \\
\hline $\begin{array}{c}\text { Popova et al. (2015) [42]; } \\
\text { El-Guendouz et al. (2016) [8]; } \\
\text { Miguel (2013) [43] }\end{array}$ & Morocco & $\begin{array}{l}\text { Diterpenes, flavonoids, } \\
\text { phenolic acid esters }\end{array}$ \\
\hline Huang et al. (2014) [13] & Nepal & $\begin{array}{c}\text { Sesquiterpenoids, flavonoids } \\
\text { and neo-flavonoids }\end{array}$ \\
\hline $\begin{array}{l}\text { Huang et al. (2014) [13]; } \\
\text { Silva-Carvalho et al. (2015) [4] }\end{array}$ & Poland & Flavonoids, phenolic acids \\
\hline $\begin{array}{c}\text { Huang et al. (2014) [13]; } \\
\text { Silva-Carvalho et al., (2015) [4]; } \\
\text { Miguel (2013) [43] }\end{array}$ & Portugal & \\
\hline Inui et al. (2012) [44] & Solomon & $\begin{array}{c}\text { Prenylated flavonoids, } \\
\text { stilbenes }\end{array}$ \\
\hline Bankova et al. (2002) [33] & Switzerland & Terpenoids \\
\hline $\begin{array}{c}\text { Bankova (2005) [29]; Martinotti } \\
\text { (2015) [41] }\end{array}$ & Taiwan & C-prenyl-flavanones \\
\hline Miguel (2013) [43] & Tunisia & Flavonoids, phenolic acids \\
\hline $\begin{array}{l}\text { Popova et al. (2005) [45]; Doganli } \\
\text { (2016) [46] }\end{array}$ & Turkey & $\begin{array}{l}\text { Diterpenes, flavonoids, } \\
\text { phenolic acids }\end{array}$ \\
\hline Bankova (2005) [29] & Venezuela & $\begin{array}{l}\text { Polyisoprenylated } \\
\text { benzophenones }\end{array}$ \\
\hline
\end{tabular}

Propolis has been used as a folk medicine since 300 BC owing to the multitude of its beneficial health effects $[47,48]$, which have motivated a vast array of applications in several health sciences. It has been used as an ingredient in dental hygiene (e.g., toothpastes and mouthwashes) and cosmetic (e.g., creams and lotions) products, as well as a chemical food preservative $[49,50]$. The first scientific report on propolis was published in 1908, detailing its composition and chemical actions [51,52]. Propolis contains many dozens of compounds, mainly polyphenols, resins, flavonoids, essential oils, fatty acids, wax, pollen and other organic substances [53,54]. It also comprises vitamins (B complex, C and E) and relevant minerals such as zinc, magnesium, copper, iron, manganese, nickel and calcium $[55,56]$. Owing to its chemical richness, propolis has a myriad of therapeutic properties, although the best studied are antioxidant, anti-inflammatory, immunomodulatory, antibacterial, antiviral, antifungal and antiproliferative [4,57]. In contrast, little attention 
has been given to the beneficial effects of propolis in cardiovascular health. In this paper, the authors identify the main propolis varieties and pharmacological compounds with the most promising therapeutic benefits, as well as the physiological mechanisms through which those benefits are attained.

\section{Cardiovascular Effects of Propolis}

Cardiovascular diseases are the number one cause of mortality globally, representing a high economic burden and deeply impacting the patients' quality of life [58-60]. Given the continuous need for new drugs and especially considering the dependence of developing countries on traditional medicines [61], a clarification on the cardiovascular benefits of propolis is warranted. As reviewed in this paper, the cardiovascular effects of propolis are attributed to a combination of several biological activities such as antioxidant, anti-inflammatory, immunomodulatory, antihypertensive, anti-atherosclerotic and antiangiogenic, which are often interrelated with each other. The next sections detail the main cardiovascular effects of different varieties of propolis.

\subsection{Anti-Atherosclerotic Effect}

Atherosclerosis is a chronic condition characterized by the progressive hardening and narrowing of arteries, consequently reducing perfusion to organs. It is caused by the accumulation of fatty plaques in their inner wall, consisting of low-density lipoprotein (LDL), cellular waste and surrounding materials [62]. High LDL and low high-density lipoprotein (HDL) levels are important risk factors. In atherosclerosis, the vascular endothelium becomes permeable to the passage of serum lipids, especially LDL, into the arterial wall. In the subendothelial space, the oxidation of LDL activates endothelial cells into producing adhesion molecules, leading to the recruitment of circulating monocytes and $\mathrm{T}$ lymphocytes. Monocytes become scavenger receptor-expressing macrophages, uptake oxLDL and become foamy cells before suffering apoptosis. They also release pro-inflammatory cytokines and reactive oxygen species (ROS) to maintain LDL oxidation. With the progression of the condition, smooth muscle and connective tissue proliferate, and dystrophic calcification ensues, leading to the hardening of the atherosclerotic lesion and bulging into the arterial lumen, restricting perfusion. The atherosclerotic lesion is more susceptible to oxidative and mechanical lesions and becomes progressively more fragile, which can culminate in plaque rupture, initiating a hemostatic process that will further decrease perfusion and precipitate the acute atherosclerosis manifestations.

The anti-atherosclerotic effects of propolis are attributed to its ability to modulate both the serum lipoprotein profile and their handling by vascular tissues and infiltrating leucocytes. These properties and respective studies are listed in Table 2.

Table 2. Description and main results of the most relevant studies assessing the anti-atherosclerotic activity of propolis.

\begin{tabular}{|c|c|c|c|c|c|}
\hline Authors & Variety/Substance & $\begin{array}{l}\text { Dose/Concentration } \\
\text { and Duration of } \\
\text { Treatment }\end{array}$ & Study Type & $\begin{array}{l}\text { Experimental } \\
\text { Model }\end{array}$ & Main Results \\
\hline $\begin{array}{c}\text { Xuan et al. (2014) } \\
\text { [63] }\end{array}$ & $\begin{array}{l}\text { Ethanolic extracts } \\
\text { of Chinese or } \\
\text { Brazilian green } \\
\text { propolis }\end{array}$ & $12.5 \mu \mathrm{g} / \mathrm{mL}$ & In vitro & $\begin{array}{l}\text { Human umbilical } \\
\text { vein endothelial } \\
\text { cell culture }\end{array}$ & $\begin{array}{c}\text { Inhibition of } \\
\text { phosphatidylcholine- } \\
\text { specific phospholipase C } \\
\text { reactive oxygen species } \\
\text { scavengingSuppression } \\
\text { of nuclear factor kappa } \\
\text { B pathway }\end{array}$ \\
\hline $\begin{array}{c}\text { Tian et al. (2015) } \\
{[64]}\end{array}$ & $\begin{array}{l}\text { Ethanolic extract of } \\
\text { Chinese propolis }\end{array}$ & $\begin{array}{c}\text { 7.5, } 15 \text { and } 30 \\
\mathrm{mg} / \mathrm{L}\end{array}$ & In vitro & $\begin{array}{l}\text { RAW264.7 } \\
\text { macrophage } \\
\text { culture }\end{array}$ & $\begin{array}{c}\text { Suppression of } \\
\text { CD36-mediated } \\
\text { oxidized low-density } \\
\text { lipoprotein uptake } \\
\text { subsequent apoptosis of } \\
\text { plaque macrophages }\end{array}$ \\
\hline
\end{tabular}


Table 2. Cont.

\begin{tabular}{|c|c|c|c|c|c|}
\hline Authors & Variety/Substance & $\begin{array}{c}\text { Dose/Concentration } \\
\text { and Duration of } \\
\text { Treatment }\end{array}$ & Study Type & $\begin{array}{l}\text { Experimental } \\
\text { Model }\end{array}$ & Main Results \\
\hline $\begin{array}{l}\text { Saavedra et al. } \\
\text { (2016) [65] }\end{array}$ & $\begin{array}{l}\text { Ethanolic extract of } \\
\text { Chilean propolis }\end{array}$ & $\begin{array}{c}1,2.5,5.0,7.5,10 \\
\mu \mathrm{g} / \mathrm{mL}\end{array}$ & In vitro & $\begin{array}{l}\text { RAW264.7 } \\
\text { macrophage } \\
\text { culture }\end{array}$ & $\begin{array}{c}\text { Concentration- } \\
\text { dependent inhibition of } \\
\text { matrix } \\
\text { metalloproteinase-9 }\end{array}$ \\
\hline Li et al. (2012) [66] & $\begin{array}{l}\text { Ethanolic extract of } \\
\text { Chinese propolis }\end{array}$ & $\begin{array}{c}50,100 \text { or } 200 \\
\mathrm{mg} / \mathrm{kg} / \text { day for } 10 \\
\text { weeks }\end{array}$ & In vitro & $\begin{array}{c}\text { High-fat } \\
\text { diet-induced type } \\
2 \text { diabetic mice }\end{array}$ & $\begin{array}{l}\text { Decrease in the hepatic } \\
\text { content of cholesterol } \\
\text { and triglycerides. } \\
\text { Decrease in rate of } \\
\text { hepatic synthesis of } \\
\text { triglycerides }\end{array}$ \\
\hline $\begin{array}{l}\text { Daleprane et al. } \\
\text { (2012) [67] }\end{array}$ & $\begin{array}{l}\text { Ethanolic extract of } \\
\text { Brazilian green, } \\
\text { red and brown } \\
\text { propolis }\end{array}$ & $\begin{array}{l}250 \mathrm{mg} / \mathrm{kg} \text { per day } \\
\text { for } 4 \text { weeks }\end{array}$ & In vivo & $\begin{array}{l}\text { Low-density } \\
\text { lipoprotein } \\
\text { receptor knockout } \\
\text { mice receiving a } \\
\text { cholesterol- } \\
\text { enriched diet to } \\
\text { induce } \\
\text { atherosclerotic } \\
\text { lesions }\end{array}$ & $\begin{array}{c}\text { Reduction of } \\
\text { atherosclerotic lesions } \\
\text { through modulation of } \\
\text { inflammatory and } \\
\text { angiogenic factors } \\
\text { (highest activity for red } \\
\text { propolis) }\end{array}$ \\
\hline $\begin{array}{c}\text { Azab et al. (2013) } \\
\text { [68] }\end{array}$ & $\begin{array}{l}\text { Aqueous extract of } \\
\text { Lybian propolis }\end{array}$ & $\begin{array}{c}200 \mathrm{mg} / \mathrm{kg} \text { for } 30 \\
\text { days }\end{array}$ & In vitro & $\begin{array}{l}\text { Lead acetate } \\
\text { intoxicated male } \\
\text { albino mice }\end{array}$ & $\begin{array}{l}\text { Prevention of the } \\
\text { increase in serum } \\
\text { cholesterol, triglycerides, } \\
\text { low-density lipoprotein } \\
\text { and very low-density } \\
\text { lipoprotein, together } \\
\text { with the increase in } \\
\text { high-density lipoprotein }\end{array}$ \\
\hline $\begin{array}{c}\text { Fang et al. (2013) } \\
\text { [69] }\end{array}$ & $\begin{array}{l}\text { Ethanolic extract of } \\
\text { Chinese propolis }\end{array}$ & $\begin{array}{l}160 \mathrm{mg} / \mathrm{kg} / \mathrm{day} \\
\text { for } 14 \text { weeks }\end{array}$ & In vitro & $\begin{array}{l}\text { Apoprotein E } \\
\text { knockout mice fed } \\
\text { a high-fat diet }\end{array}$ & $\begin{array}{c}\text { Inhibition of } \\
\text { atherosclerosis through } \\
\text { cholesterol modulation, } \\
\text { inflammation regulation } \\
\text { and inhibition of } \\
\text { endothelin and vascular } \\
\text { endothelial growth } \\
\text { factor secretion }\end{array}$ \\
\hline $\begin{array}{c}\text { Oršolić et al. (2019) } \\
\text { [70] }\end{array}$ & $\begin{array}{l}\text { Ethanolic extract of } \\
\text { Croatian propolis }\end{array}$ & $\begin{array}{c}50 \mathrm{mg} / \mathrm{kg} \text { for } 30 \\
\text { days }\end{array}$ & In vitro & $\begin{array}{l}\text { High-fat diet-fed } \\
\text { mice }\end{array}$ & $\begin{array}{l}\text { Prevention of the } \\
\text { increase in serum } \\
\text { cholesterol, triglycerides, } \\
\text { low-density lipoprotein } \\
\text { and very low-density } \\
\text { lipoprotein, together } \\
\text { with the increase in } \\
\text { high-density lipoprotein }\end{array}$ \\
\hline
\end{tabular}

Propolis administered orally affects the lipoprotein profile in several animal models of atherosclerosis. In lead acetate intoxicated mice, Lybian propolis administrated orally $(200 \mathrm{mg} / \mathrm{kg}$ ) for 30 days was shown to prevent an increase in the serum cholesterol, triglycerides (TG), LDL and very low-density lipoprotein (VLDL) levels, while the HDL levels increased [71]. The same beneficial effect was found for Croatian propolis (50 mg/ $\mathrm{kg}$ ) in high-fat diet-fed mice [70]. These effects seem to be in part attributed to the reversal of cholesterol transport, the expression of ATP-binding cassette transporters A1 and G1 and to the direct stimulation of HDL synthesis [72]. A similar observation was made in healthy Sprague-Dawley rats, where Chinese propolis decreased the hepatic 
content of cholesterol and TG, besides decreasing the rate of TG hepatic synthesis [66]. Studies carried out in transgenic animals further support these results. In apoprotein $\mathrm{E}$ knockout $\left(\mathrm{ApoE}^{-/-}\right)$mice fed with a high-fat diet, an ethanolic extract of Chinese propolis $(160 \mathrm{mg} / \mathrm{kg} /$ day for 14 weeks) inhibited atherosclerosis through a combination of cholesterol modulation, inflammation regulation and the inhibition of endothelin and vascular endothelial growth factor (VEGF) secretion [69]. The administration of polyphenols from Brazilian red propolis ( $250 \mathrm{mg} / \mathrm{kg} /$ day) during four weeks to LDL receptor knockout $\left(\mathrm{LDLr}^{-/-}\right)$mice promoted a decrease in TG, total cholesterol and non-high-density lipoprotein levels [67]. When treated with Brazilian green propolis, rich in artepillin $C$ ((E)-3-(4-hydroxy-3,5-bis[3-methylbut-2-enyl]phenyl)prop-2-enoic acid), pinocembrin ((2S)5,7-dihydroxy-2-phenyl-2,3-dihydrochromen-4-one) and kaempferol (3,5,7-trihydroxy-2(4-hydroxyphenyl)chromen-4-one) or with Chilean brown propolis, rich in pinocembrin, caffeic acid phenethyl ester (CAPE, 2-phenylethyl (E)-3-(3,4-dihydroxyphenyl)prop-2enoate), quercetin (2-(3,4-dihydroxyphenyl)-3,5,7-trihydroxychromen-4-one) and galangin (3,5,7-trihydroxy-2-phenylchromen-4-one), $\mathrm{LDLr}^{-/-}$mice also showed lower non-HDL levels. In mice, artepillin $C$ is also known to act on adipose tissue, promoting the conversion of white adipocytes into brown adipocytes (browning), suggesting a potential role in increasing the energy expenditure and, thus, in preventing/treating metabolic disorders such as obesity and diabetes [73]. A Chinese propolis variety was also found to promote reverse cholesterol transport (i.e., from peripheral tissues back to the liver) by increasing both the serum HDL levels and the expression of efflux transporters ATP-binding cassette transporter A1 and G1, thus restraining the progression of the atherosclerotic lesion [74].

Besides modulating the lipid profile, propolis has also been found to positively interfere with the vascular handling of LDL by plaque macrophages. The advanced and destabilized atherosclerotic plaque exhibits prominent macrophage apoptosis, whereas, when it occurs early in the plaque evolution, it is associated with less cellularity and with slower lesion progression. Ethanolic extracts of Chinese propolis show potential in shielding macrophages from oxidized low-density lipoprotein (oxLDL)-mediated apoptosis. This variety suppressed CD36-mediated oxLDL uptake and the subsequent apoptosis induced by the endoplasmic reticulum stress C/EBP homologous protein (CHOP) pathway [64]. Propolis is also known to interfere with the activity of matrix metalloproteinases. These enzymes are active during tissue remodeling and repair but are also implicated in the atherosclerotic plaque destabilization [65]. Matrix metalloproteinase-9 (MMP-9), in particular, is expressed by plaque macrophages and contributes to its destabilization in both animals and humans $[75,76]$. The ethanolic extract of Chilean propolis, as well as isolated pinocembrin, was found to display a concentration-dependent inhibitory effect over MMP-9 [65]. Propolis also modulates vascular smooth muscle (VSM) cell proliferation and migration inside the plaque, an effect that was mostly attributed to CAPE [1].

Finally, propolis also slows the progression of atherosclerosis by preventing vascular endothelial dysfunction through its antioxidant, anti-inflammatory and immunomodulatory activities. Chinese and Brazilian propolis show inhibitory activity against phosphatidylcholine-specific phospholipase $C$ in human umbilical vein endothelial cells (HUVECs). This is an important member of the phospholipase $C$ family and thought to be involved in the initiation and progression of atherosclerosis. Furthermore, these varieties also showed important ROS scavenging and nuclear factor kappa B (NF- $\mathrm{kB}$ ) suppressor effects, which also contribute to their anti-atherosclerotic activity [63].

\subsection{Anti-Hemostatic Activity}

Hemostasis is the set of processes that enable closing off ruptured blood vessels while preventing vascular obstruction (i.e., fibrinolytic activity), as well as maintaining adequate blood rheology [77]. These processes include the spasm of affected blood vessels, platelet plug formation and blood clotting. Once the blood vessels are repaired, fibrinolysis ensues. Upon vessel damage, platelets adhere to the damage site, become activated and attract more platelets in a positive feedback loop via the secretion of several autacoids. Platelets 
then aggregate to one another via interactions between surface receptors and extracellular ligands to form a hemostatic plug. The clotting process then culminates in the formation of a fibrin matrix, which stabilizes and reinforces the formed plug [78]. The anti-hemostatic activities of propolis and respective studies are listed in Table 3.

Table 3. Description and main results of the most relevant studies assessing the anti-hemostatic activity of propolis.

\begin{tabular}{|c|c|c|c|c|c|}
\hline Authors & Variety/Substance & $\begin{array}{c}\text { Dose/Concentration } \\
\text { and Duration of } \\
\text { Treatment }\end{array}$ & Study Type & $\begin{array}{l}\text { Experimental } \\
\text { Model }\end{array}$ & Main Results \\
\hline $\begin{array}{l}\text { Ohkura et al. } \\
\text { (2012) [79] }\end{array}$ & $\begin{array}{l}\text { Ethanolic extract of } \\
\text { Brazilian green } \\
\text { propolis }\end{array}$ & $0.5 \%(w / w)$ & In vitro & $\begin{array}{l}\text { Human umbilical } \\
\text { vein endothelial } \\
\text { cell (HUVEC) } \\
\text { culture incubated } \\
\text { with tumor } \\
\text { necrosis factor } \\
\text { alpha }\end{array}$ & $\begin{array}{l}\text { Suppression of tumor } \\
\text { necrosis factor } \\
\text { alpha-mediated } \\
\text { secretion of } \\
\text { plasminogen activator } \\
\text { inhibitor-1 }\end{array}$ \\
\hline $\begin{array}{l}\text { Ohkura et al. } \\
\text { (2016) [80] }\end{array}$ & $\begin{array}{l}\text { Ethanolic extract of } \\
\text { Brazilian green } \\
\text { propolis }\end{array}$ & $\begin{array}{c}0.5 \%(w / w) \text { in } \\
\text { medium fat diet } \\
\text { for } 2,4 \text { or } 8 \text { weeks }\end{array}$ & In vitro & $\begin{array}{l}\text { Lipopolysaccharide- } \\
\text { induced } \\
\text { inflammation in } \\
\text { Kwl:ICR mice }\end{array}$ & $\begin{array}{l}\text { Attenuation of } \\
\text { lipopolysaccharide- } \\
\text { mediated secretion of } \\
\text { plasminogen activator } \\
\text { inhibitor- } 1 \text { and of its } \\
\text { plasma activity after } 8 \\
\text { weeks treatment }\end{array}$ \\
\hline $\begin{array}{c}\text { Bojic et al. (2018) } \\
\text { [81] }\end{array}$ & $\begin{array}{l}\text { Ethanolic extracts } \\
\text { from Croatian, } \\
\text { Macedonian and } \\
\text { Bosnian propolis }\end{array}$ & $\begin{array}{c}\text { Different } \\
\text { concentrations } \\
\text { until reaching the } \\
\text { minimal } \\
\text { antiaggregatory } \\
\text { concentration }\end{array}$ & In vitro & $\begin{array}{l}\text { Whole human } \\
\text { blood }\end{array}$ & $\begin{array}{l}\text { Reduction in adenosine } \\
\text { diphosphate-induced } \\
\text { aggregant effect, with } \\
\text { minimal antiaggregatory } \\
\text { concentrations ranging } \\
\text { from } 5 \mu \mathrm{M} \text { to } 10.4 \mathrm{mM}\end{array}$ \\
\hline $\begin{array}{l}\text { Ohkura et al. } \\
\text { (2012) [79] }\end{array}$ & $\begin{array}{c}\text { Ethanolic extract of } \\
\text { Brazilian green } \\
\text { propolis }\end{array}$ & $\begin{array}{l}12.5 \mathrm{mg} / \mathrm{kg} \\
\text { administered } \\
\text { intraperitoneally } \\
\text { for } 7 \text { days }\end{array}$ & In vivo & $\begin{array}{l}\text { Lipopolysaccharide- } \\
\text { induced } \\
\text { inflammation in } \\
\text { Kwl:ICR mice }\end{array}$ & $\begin{array}{l}\text { Attenuation of } \\
\text { lipopolysaccharide- } \\
\text { mediated secretion of } \\
\text { plasminogen activator } \\
\text { inhibitor-1 and of its } \\
\text { plasma activity }\end{array}$ \\
\hline $\begin{array}{l}\text { Martina et al. } \\
\text { (2018) [82] }\end{array}$ & $\begin{array}{l}\text { HDI Origins }{ }^{\mathrm{TM}} \text { Bee } \\
\text { Propolis } \\
\text { (Indonesian } \\
\text { propolis) }\end{array}$ & $\begin{array}{l}65 \mathrm{mg} / \mathrm{kg} / \text { day } \\
\text { administered } \\
\text { orally for } 12 \text { days }\end{array}$ & In vivo & $\begin{array}{c}\text { Healthy Double } \\
\text { Distsch Webster } \\
\text { mice }\end{array}$ & Increase in bleeding time \\
\hline
\end{tabular}

Propolis extracts have demonstrated antiplatelet activity both in vitro and in vivo. Ethanolic extracts from Southeastern Europe samples reduce the adenosine diphosphate (ADP)-induced platelet aggregation when added to blood samples from young patients with thrombophilia, with higher activity being attributed to either low luteolin $(2-(3,4-$ dihydroxyphenyl)-5,7-dihydroxychromen-4-one) content and/or higher pinocembrin-7methyleter content [81]. Water propolis extracts added to human platelet-rich plasma also inhibited platelet aggregation induced by ADP, the thrombin receptor activator peptide and collagen, with similar results being found for several individual propolis flavonoids, such as galangin [83], pinostrobin ((2S)-5-hydroxy-7-methoxy-2-phenyl-2,3-dihydrochromen4-one) [83], chrysin (5,7-dihydroxy-2-phenylchromen-4-one) [84] and CAPE, the latter specifically targeting collagen-induced aggregation $[83,85]$. Propolis also interferes with hemostasis by suppressing the production of plasminogen activator inhibitor-1 (PAI-1), an inhibitor of fibrinolysis that is induced in inflammatory states. The ethanolic extract of Brazilian green propolis suppressed the tumor necrosis factor alpha (TNF- $\alpha$ )-mediated production of PAI-1 in cultured HUVECs [79]. Similar results were found in animal studies. The oral supplementation of mice with an ethanolic extract of Brazilian green propolis 
for eight weeks attenuated the lipopolysaccharide (LPS)-induced increase in PAI-1 and its plasma activity [80]. Similarly, the intraperitoneal administration of Brazilian green propolis $(12.5 \mathrm{mg} / \mathrm{kg})$ also prevented the LPS-mediated increase in PAI-1 [79]. In an in vivo study, the antiplatelet activity has shown to increase the bleeding time in mice receiving Indonesian propolis in a magnitude comparable to that of aspirin (2-acetyloxybenzoic acid) [82]. Propolis also shows an anticoagulant effect indeed potent enough to interfere with the activity of warfarin. CD-1 mice receiving both warfarin $(\sim 0.08 \mathrm{mg} /$ day $)$ and an ethanolic extract of Turkish propolis ( $100 \mathrm{mg} / \mathrm{kg} /$ day) for eight days showed lower international normalized ratio (INR) values compared with mice that only received warfarin [86].

\subsection{Antihypertensive Activity}

Hypertension leads to different types of damage to the cardiovascular system, both morphological and functional. Hypertension causes an increase in the arterial shear stress, which damages the endothelium, accelerates atherosclerosis and precipitates the rupture of unstable plaques. Endothelial damage then leads to microhemorrhages, microinfarctions and exudates in the microvascular beds, together with arterial and ventricular remodeling, which combine to cause end-organ damage [87].

The antihypertensive effects of propolis have been studied in different animal models (see Table 4) and have been attributed to several biological activities, including the modulation of vascular tone, anti-inflammatory and antioxidant [88].

Table 4. Description and main results of the most relevant studies assessing the antihypertensive activity of propolis.

\begin{tabular}{|c|c|c|c|c|c|}
\hline Authors & Variety/Substance & $\begin{array}{c}\text { Dose/Concentration } \\
\text { and Duration of } \\
\text { Treatment }\end{array}$ & Study Type & Experimental Model & Results \\
\hline $\begin{array}{c}\text { Kubota et al. (2004) } \\
\text { [89] }\end{array}$ & $\begin{array}{l}\text { Ethanolic extract of } \\
\text { Brazilian propolis }\end{array}$ & $\begin{array}{c}0.5 \%(w / w) \text { for } 4 \\
\text { weeks }\end{array}$ & In vitro & $\begin{array}{c}\text { Spontaneously } \\
\text { hypertensive rats }\end{array}$ & $\begin{array}{l}\text { Potentiation of } \\
\text { acetylcholine- } \\
\text { dependent aortic } \\
\text { vasorelaxation }\end{array}$ \\
\hline $\begin{array}{l}\text { Gogebakan et al. } \\
\text { (2012) [90] }\end{array}$ & $\begin{array}{l}\text { Ethanolic extract of } \\
\text { Turkish propolis }\end{array}$ & $\begin{array}{l}200 \mathrm{mg} / \mathrm{kg} \text { orally } \\
\text { administered in } \\
\text { the last } 5 \text { days of } \\
\text { the study }\end{array}$ & In vivo & $\begin{array}{c}\text { Wistar rats with } \\
\text { hypertension } \\
\text { following } \\
\mathrm{N}^{\omega} \text {-nitro-L-arginine } \\
\text { methyl ester } \\
\text {-administration (15 } \\
\text { days) }\end{array}$ & $\begin{array}{c}\text { Tyrosine } \\
\text { hydroxylase- } \\
\text { mediated decrease in } \\
\text { catecholamine } \\
\text { synthesis }\end{array}$ \\
\hline $\begin{array}{c}\text { Aoi et al. (2013) } \\
\text { [91] }\end{array}$ & $\begin{array}{l}\text { Ethanolic extract of } \\
\text { Brazilian propolis }\end{array}$ & $\begin{array}{c}0.1 \% \text { and } 0.5 \% \\
(w / w) \text { for } 8 \text { weeks }\end{array}$ & In vivo & $\begin{array}{l}\text { Otsuka Long-Evans } \\
\text { Tokushima Fatty rats }\end{array}$ & $\begin{array}{c}\text { Blood pressure } \\
\text { decrease }\end{array}$ \\
\hline $\begin{array}{c}\text { Teles et al. (2015) } \\
\text { [92] }\end{array}$ & $\begin{array}{c}\text { Ethanolic extract of } \\
\text { Brazilian red } \\
\text { propolis }\end{array}$ & $\begin{array}{c}150 \mathrm{mg} / \mathrm{kg} / \text { day } \\
\text { for } 60 \text { days }\end{array}$ & In vivo & $\begin{array}{l}5 / 6 \text { renal ablation } \\
\text { model in Wistar rats }\end{array}$ & $\begin{array}{c}\text { Attenuation of blood } \\
\text { pressure increase }\end{array}$ \\
\hline $\begin{array}{l}\text { Mujica et al. (2017) } \\
\text { [93] }\end{array}$ & $\begin{array}{l}\text { Propyleneglycolic } \\
\text { extract of Chilean } \\
\text { propolis }\end{array}$ & $\begin{array}{l}3 \%(w / w) \text { orally } \\
\text { administrated (15 } \\
\text { drops, twice daily) } \\
\text { for } 90 \text { days }\end{array}$ & In vivo & Hypertensive patients & $\begin{array}{l}\text { Blood pressure } \\
\text { decrease }\end{array}$ \\
\hline
\end{tabular}

In $\mathrm{N}^{\omega}$-nitro-L-arginine methyl ester (L-NAME)-induced hypertensive Wistar rats, Turkish propolis reduced blood pressure (BP), which was attributed to the ROS scavenging activity of flavonoids, as well as to the presence of arginine, which stimulates nitric oxide synthase (NOS) activity and offsets the NOS-blocking activity of L-NAME. Both of these actions increase the nitric oxide (NO) availability in the VSM, leading to vasorelaxation [94]. Moreover, Uruguayan propolis increased the expression of endothelial nitric oxide synthase (eNOS) and decreased nicotinamide adenine dinucleotide phosphate oxidase (NOX) activity, also increasing the endothelial NO bioavailability [95]. 
Ethanolic extracts of Turkish propolis displayed a moderate, although nonsignificant, BP-lowering effect in L-NAME-induced hypertensive rats. This effect was attributed to a decrease in tyrosine hydroxylase-mediated catecholamine synthesis [90]. In fact, the co-administration of propolis, pollen and CAPE may mediate a decrease in TH activity in the heart, adrenal glands and hypothalamus of hypertensive rats [96].

In high-salt intake hypertensive rats, Chinese propolis reduced the BP by reducing oxidative stress via a decrease in NOX expression. The consequent increase in endothelial NO bioavailability, together with an anti-inflammatory action (reduction of TNF- $\alpha$ and interleukin (IL)-6 levels) and with an improvement of the myocardial contractile function, ameliorated hypertension in this model [97].

In spontaneously hypertensive rats (SHR), a Brazilian propolis variety, rich in caffeoylquinic acids (CQAs), reduced BP due to its anti-inflammatory action, although a direct vasorelaxant action may also contribute to the response [98]. In another Brazilian propolis variety, the antihypertensive effect was, in fact, attributed to the enhancement of endothelium-dependent vasorelaxation [89]. Whether this effect results from a muscarinic receptor agonistic activity or from the potentiation of its downstream pathway is yet to be clarified. Finally, the combination of a poplar-based Chinese Propolis variety with royal jelly and bee venom reduced blood pressure via a decrease of the serum levels of angiotensin II, endothelin- 1 and transforming growth factor- $\beta$ [99].

In a rat model of renal ablation, the administration of Brazilian red propolis attenuated hypertension, again probably through anti-inflammatory and antioxidant effects [92]. The incorporation of an ethanolic extract of Brazilian propolis in the diet of Otsuka Long-Evans Tokushima Fatty (OLETF) rats during an eight-week period decreased the BP, presumably due to the suppression of metabolic acidosis-induced hypertension [91].

Several randomized clinical trials have investigated the antihypertensive potential of propolis. In a study conducted on healthy subjects, the administration of a commercial propolis supplement $(500 \mathrm{mg}$, twice-daily) resulted in a significant decrease in BP after two months [100]. A double-blind, placebo-controlled study demonstrated that the administration of Beepolis ${ }^{\circledR}$ (Laboratorio Rotterdam Ltda, San Javier, Chile), a 3\% Chilean Propolis solution in propylene glycol, decreased BP in hypertensive patients over a period of 90 days [93]. However, in another double-blind, placebo-controlled study, the co-administration of Brazilian Green Propolis ( $500 \mathrm{mg} /$ day) and antihypertensive drugs to patients with hypertension and chronic kidney disease showed no change in BP after a period of 12 months [88].

Several studies have identified several compounds in propolis with putative vasoactive properties. Several CQAs, namely 3,4-diCQA, 3,5-diCQA and 3,4,5-triCQA, were shown to reduce $\mathrm{BP}$ when administered orally at a $10 \mathrm{mg} / \mathrm{kg}$ dose, probably due to their anti-inflammatory properties [98]. The flavonoids kaempferide (3,5,7-trihydroxy-2-(4-methoxyphenyl) chromen-4-one), dihydrokaempferide (3,5,7-trihydroxy-2-(4-methoxyphenyl)-2,3dihydrochromen-4-one), isosakuranetin ((2S)-5,7-dihydroxy-2-(4-methoxyphenyl)-2,3dihydrochromen-4-one) and betuletol (3,5,7-trihydroxy-6-methoxy-2-(4-methoxyphenyl) chromen-4-one) were found to be the main active substances responsible for the BPlowering effects of the Brazilian ethanolic propolis in SHRs [101]. Furthermore, CAPE is a major component of European and Asian propolis and displays a vasorelaxant activity in several vascular beds in vitro. This activity is currently attributed to the stimulation of NO release by the endothelium and to hyperpolarizing effects on VSM cells [102]. The flavonoid chrysin has antioxidant effects in L-NAME-induced hypertensive Wistar rats by increasing the activities of glutathione reductase and glutathione-S-transferase [103]. The prevention of cardiac oxidative stress is probably responsible for the complex interplay of the blood pressure-lowering activities, including the decrease in left ventricular function, decrease in plasma angiotensin-II concentration and prevention of NO loss, together with the increase in cardiac hexo oxygenase and cyclic guanosine monophosphate concentrations [104]. 


\subsection{Antiangiogenesis Activity}

Angiogenesis refers to the tightly controlled and complex process of the formation of new blood vessels from preexisting vessels, essential for tissue development, regeneration and repair [105]. Angiogenesis is initiated when tissues sense a hypoxic environment, responding with the stabilization and translocation of the transcription factor hypoxiainducible factor 1-alpha $\left(\mathrm{HIF} 1_{\alpha}\right)$ to the nucleus, where it induces angiogenic factors such as VEGF. This factor is then released and binds to the VEGF2 receptor on neighbor endothelial cells, inducing cell migration, proliferation and sprouting [106]. Dysfunctional angiogenesis is present in several pathological states, such as inflammation and cancer, leading to persistent and inappropriate blood vessel formation $[107,108]$. It also contributes to the pathophysiology of atherosclerosis-namely, to the proliferation of the fatty plaque and consequent destabilization, which can lead to intraplaque hemorrhage and plaque rupture. Therefore, antiangiogenic strategies may hinder the progression of the disease [109]. The antiangiogenic activities of propolis and respective studies are listed in Table 5.

Table 5. Description and main results of the most relevant studies assessing the anti-angiogenic activity of propolis.

\begin{tabular}{|c|c|c|c|c|c|}
\hline Authors & Variety/Substance & Dose & $\begin{array}{l}\text { Study } \\
\text { Type }\end{array}$ & $\begin{array}{l}\text { Experimental } \\
\text { Model }\end{array}$ & Main Results \\
\hline $\begin{array}{l}\text { Izuta et al. (2009) } \\
\text { [110] }\end{array}$ & $\begin{array}{c}\text { Ethanolic extract of } \\
\text { Chinese red } \\
\text { propolis }\end{array}$ & $0.3-3.0 \mu \mathrm{g} / \mathrm{mL}$ & In vitro & \multirow{4}{*}{ HUVEC culture } & $\begin{array}{l}\text { Suppression of vascular } \\
\text { endothelial growth } \\
\text { factor-induced HUVEC } \\
\text { proliferation and } \\
\text { migration }\end{array}$ \\
\hline $\begin{array}{l}\text { Chikaraishi et al. } \\
\text { (2010) [111] }\end{array}$ & $\begin{array}{l}\text { Aqueous extract of } \\
\text { Brazilian green } \\
\text { propolis }\end{array}$ & $100 \mathrm{mg} / \mathrm{mL}$ & In vitro & & $\begin{array}{l}\text { Suppression of vascular } \\
\text { endothelial growth } \\
\text { factor-induced HUVEC } \\
\text { proliferation, migration, } \\
\text { and tube formation, } \\
\text { attributed to } \\
\text { caffeoylquinic acids }\end{array}$ \\
\hline $\begin{array}{l}\text { Kunimasa et al. } \\
\text { (2011) [112] }\end{array}$ & $\begin{array}{c}\text { Ethanolic extract of } \\
\text { Brazilian green } \\
\text { propolis }\end{array}$ & $\begin{array}{c}6.25,12.5 \text { and } 25 \\
\mu \mathrm{g} / \mathrm{mL}\end{array}$ & In vitro & & $\begin{array}{l}\text { Concentration-dependent } \\
\text { induction of apoptosis in } \\
\text { tube-forming HUVECs }\end{array}$ \\
\hline \multirow[t]{2}{*}{$\begin{array}{l}\text { Meneghelli et al. } \\
\text { (2013) [113] }\end{array}$} & \multirow{2}{*}{$\begin{array}{l}\text { Hydro-alcoholic } \\
\text { extract of Brazilian } \\
\text { propolis }\end{array}$} & $\begin{array}{c}100,130,150 \text { and } \\
180 \mu \mathrm{g} / \mathrm{mL}\end{array}$ & In vitro & & $\begin{array}{l}\text { Significant decrease in cell } \\
\text { viability, proliferation, } \\
\text { migration and in capillary } \\
\text { tube formation }\end{array}$ \\
\hline & & $450 \mathrm{mg} / \mathrm{kg}$ & In vivo & $\begin{array}{l}\text { Chick embryo } \\
\text { chorioallantoic } \\
\text { membrane assay }\end{array}$ & $\begin{array}{l}\text { Inhibition of angiogenesis } \\
\text { and vasculogenesis }\end{array}$ \\
\hline $\begin{array}{c}\text { Cuevas et al. (2014) } \\
\text { [114] }\end{array}$ & $\begin{array}{l}\text { Ethanolic extract of } \\
\text { Chilean propolis }\end{array}$ & $250 \mathrm{mg} / \mathrm{kg}$ & In vitro & $\begin{array}{l}\text { Aortic rings from } \\
\text { low-density } \\
\text { lipoprotein receptor } \\
\text { knockout male mice }\end{array}$ & $\begin{array}{l}\text { Decreased expression of } \\
\text { vascular endothelial } \\
\text { growth factor A }\end{array}$ \\
\hline \multirow[b]{2}{*}{$\begin{array}{c}\text { Cuevas et al. (2015) } \\
\text { [115] }\end{array}$} & \multirow[b]{2}{*}{$\begin{array}{l}\text { Ethanolic extract of } \\
\text { Chilean propolis }\end{array}$} & $1-15 \mu \mathrm{g} / \mathrm{mL}$ & In vitro & HUVEC culture & $\begin{array}{l}\text { Attenuation of migration } \\
\text { and sprouting }\end{array}$ \\
\hline & & $15 \mu \mathrm{g} / \mathrm{mL}$ & In vitro & $\begin{array}{l}\text { Aortic rings from } \\
\text { male Wistar rats }\end{array}$ & $\begin{array}{c}\text { Inhibition of } \\
\text { hypoxia-inducible factor } 1 \\
\text { alpha accumulation in a } \\
\text { concentration-dependent } \\
\text { manner }\end{array}$ \\
\hline
\end{tabular}


Table 5. Cont.

\begin{tabular}{|c|c|c|c|c|c|}
\hline Authors & Variety/Substance & Dose & $\begin{array}{l}\text { Study } \\
\text { Type }\end{array}$ & $\begin{array}{l}\text { Experimental } \\
\text { Model }\end{array}$ & Main Results \\
\hline \multirow[t]{2}{*}{$\begin{array}{l}\text { Daleprane et al. } \\
\text { (2012) [116] }\end{array}$} & \multirow[t]{2}{*}{$\begin{array}{l}\text { Polyphenolic } \\
\text { extract from red } \\
\text { propolis }\end{array}$} & \multirow[t]{2}{*}{$10 \mathrm{mg} / \mathrm{L}$} & In vitro & EA.hy926 cell culture & $\begin{array}{l}\text { Angiogenesis attenuation; } \\
\text { inhibition of } \\
\text { hypoxia-induced } \\
\text { expression of vascular } \\
\text { endothelial growth factor; } \\
\text { decrease in } \\
\text { hypoxia-inducible factor } 1 \\
\text { alpha accumulation }\end{array}$ \\
\hline & & & In vitro & $\begin{array}{l}\text { Aortic rings from } \\
\text { male Wistar rats }\end{array}$ & $\begin{array}{l}\text { Sprouting of endothelial } \\
\text { cell tubular structures }\end{array}$ \\
\hline $\begin{array}{c}\text { Park et al. (2014) } \\
\text { [117] }\end{array}$ & $\begin{array}{l}\text { Ethanolic extract of } \\
\text { Korean propolis }\end{array}$ & $\begin{array}{c}6.25,12.5, \text { or } 25 \\
\mu \mathrm{g} / \mathrm{mL}\end{array}$ & In vitro & HUVEC culture & $\begin{array}{c}\text { Inhibition of proliferation } \\
\text { of HUVECs and tube } \\
\text { formation }\end{array}$ \\
\hline $\begin{array}{l}\text { Chikaraishi et al. } \\
\text { (2010) [111] }\end{array}$ & $\begin{array}{l}\text { Aqueous extract of } \\
\text { Brazilian green } \\
\text { propolis }\end{array}$ & $\begin{array}{l}300 \mathrm{mg} / \mathrm{kg} / \text { day } \\
\text { administered } \\
\text { subcutaneously } \\
\text { for } 5 \text { days }\end{array}$ & In vivo & $\begin{array}{l}\text { Oxygen-induced } \\
\text { retinopathy in } \\
\text { C57BL/6 mice }\end{array}$ & $\begin{array}{l}\text { Suppression of retinal } \\
\text { neovascularization, } \\
\text { attributed to } \\
\text { caffeoylquinic acids }\end{array}$ \\
\hline $\begin{array}{l}\text { Daleprane et al. } \\
\text { (2012) [116] }\end{array}$ & $\begin{array}{l}\text { Polyphenolic } \\
\text { extract from red } \\
\text { propolis }\end{array}$ & $10 \mathrm{mg} / \mathrm{L}$ & In vivo & $\begin{array}{l}\text { Chick embryo } \\
\text { chorioallantoic } \\
\text { membrane assay }\end{array}$ & Reduced angiogenesis \\
\hline $\begin{array}{c}\text { Park et al. (2014) } \\
\text { [117] }\end{array}$ & $\begin{array}{l}\text { Ethanolic extract of } \\
\text { Korean propolis }\end{array}$ & $\begin{array}{c}6.25,12.5 \text { or } 25 \\
\mu \mathrm{g} / \mathrm{egg}\end{array}$ & In vivo & $\begin{array}{l}\text { Chick embryo } \\
\text { chorioallantoic } \\
\text { membrane assay }\end{array}$ & Reduced angiogenesis \\
\hline
\end{tabular}

Several propolis varieties-namely, Brazilian, Chilean, Korean and Chinese Red Propolis, have demonstrated antiangiogenic activity in vitro after incubation with HUVECs. Propolis extracts reduce the endothelial cell viability by inducing apoptosis or by suppressing the cellular pathways, leading to cell migration and proliferation [63,92,95,116,118-122]. Rat aortic rings in vitro or animal models of oxygen-induced retinal neovascularization in vivo show that propolis extracts suppress tubulogenesis, an early step in angiogenesis in the embryo, through a reduced accumulation of $\mathrm{HIF} 1_{\alpha}[65,114,116]$ or by reducing the expression of VEGF [1,110,111,114].

Although, in most propolis varieties, the antiangiogenic activity is attributed to an additive action of dozens of compounds, mainly polyphenols, several isolated propolis compounds are thought to be the main contributors for this activity. Artepillin C, CAPE, galangin, kaempferol and quercetin display important antiangiogenic actions [123], which seemed to be partly related to their antioxidant activity. In fact, flavonols tended to show very strong antiangiogenic activity that seemed to be correlated to their strong antioxidant activity, while flavones possessed relatively high antiangiogenic activity, with only a limited degree of antioxidant activity [123]. In addition, CQA derivatives are thought to possess substantial antiangiogenic activity [111].

\subsection{Endothelial-Protecting Activity}

The endothelium is the innermost vascular layer and pivotal in the orchestration of the regulation of cardiovascular function, being involved in the modulation of vascular tone, maintaining blood rheology, regulating inflammatory and immune response and neovascularization [124]. As a physical barrier, the endothelium is also the first vascular defense system against a vast number of aggressions, including mechanical (i.e., shear stress), chemical and biological [125]. The endothelium is considered functional when it is highly capable of secreting NO, which displays important anti-atherosclerotic and antihemostatic activities, besides its vasorelaxant action. Oxidative stress—for example, arising 
from tissue inflammation-leads to the accumulation of ROS and reactive nitrogen species (RNS). Among the latter, peroxynitrite leads to a decrease in NO availability by both direct and indirect actions. Firstly, peroxynitrite directly decreases NO availability by directly reacting with it. Secondly, it oxidizes the tetrahydrobiopterin $\left(\mathrm{BH}_{4}\right)$ cofactor and leads to eNOS uncoupling, which further increases superoxide production. Finally, peroxynitrite also promotes protein nitration, contributing further to the dysfunction and death of endothelial cells $[126,127]$. Other pathophysiological stimuli, such as hyperglycemia, hyperlipidemia, oxLDL, hypertension [128], mental stress [129], aging [130] and exposure to specific drugs [131], can disrupt the molecular mechanisms regulating NO bioavailability. The decrease in the endothelial capacity for NO release is termed endothelial dysfunction and constitutes a main hallmark of several cardiovascular diseases [132].

Several studies detail the antioxidant effect of propolis on endothelial cells in vitro, with the vast majority using Chinese propolis varieties. The pretreatment of HUVECs with an ethanolic extract of Chinese propolis improved the oxLDL-mediated oxidative stress by decreasing NOX activation, as well as ROS and malonaldehyde generation, while increasing antioxidant enzyme activities [69]. Additionally, this variety reduced the oxLDL uptake by HUVECs by attenuating the oxLDL-induced upregulation of lectin-like oxidized low-density lipoprotein receptor-1 (LOX-1), a critical receptor in this process [133]. Furthermore, cell viability was maintained by increasing the release of lactate dehydrogenase, by the activation of caspase- 3 and by oxLDL-induced cell apoptosis in a dose-dependent way, suggesting a protective role against oxLDL-mediated endothelial dysfunction [64]. The Chinese poplar propolis protected against oxLDL-mediated endothelial dysfunction by several mechanisms, including activating the PI3K/Akt/mTOR signaling pathway, by inhibiting the LOX-1/p38 mitogen-activated protein kinase (MAPK) level, by depressing ROS production and protecting MMPs to inhibit apoptosis and autophagy [134]. Chinese propolis protects the endothelium against lipopolysaccharide-mediated endothelial dysfunction by suppressing autophagy and blocking the MAPK/NF-kB signaling pathway [135]. Hyperglycemia is another factor responsible for endothelial dysfunctional, causing the many microvascular and macrovascular complications that accompany diabetes [136]. Chinese propolis prevented the glucose-induced impairment of phenylephrine-induced contraction and endothelial-dependent vasorelaxation. Moreover, it increased the superoxide dismutase (SOD) activity and glutathione (GSH) concentration while decreasing the concentration of malonaldehyde, suggesting an important protective role against glucose-induced vascular endothelial dysfunction [137].

\subsection{Myocardial-Protecting Activity}

Cardiomyocytes, endocardial and coronary endothelial cells, as well as cardiac nerves, are all sources of NO. This mediator is necessary for normal cardiac physiology and has a protective role in heart ischemia. Oxidative and nitrosative stress are also known to promote cardiomyocyte dysfunction. Peroxynitrite impairs cardiac function through multiple mechanisms, including the activation of nuclear enzyme poly(ADP-ribose) polymerase (PARP) and of MMPs, a family of enzymes involved in protein degradation in the extracellular matrix, especially collagen and elastin. Nitrosative stress also promotes the S-nitrosylation of cysteine residues within multiple proteins and can perturb their functions [138]. Nitrosative stress is involved in the pathogenesis of acute heart failure, congestive heart failure [139,140] and coronary heart disease [118].

The pretreatment of cardiomyocytes with Malaysian propolis improved the adverse histological effects of isoproterenol-induced myocardial infarction in mice mainly through its ROS scavenging activity. A pretreatment with propolis suppressed the cardiac markers and enhanced the histopathological result through its radical-scavenging activity and potentially lipid peroxidation inhibition [55]. Several varieties of Chinese propolis have also displayed antioxidant activity against hydrogen peroxide-induced oxidative injury in rat cardiomyocytes. From all the analyzed compounds, CAPE, benzyl caffeate (BZC, benzyl (E)-3-(3,4-dihydroxyphenyl)prop-2-enoate) and cinnamylcaffeate (CNC, ([E]-3-phenylprop- 
2-enyl) [E]-3-(3,4-dihydroxyphenyl)prop-2-enoate) showed higher cytoprotective effects, followed by chrysin, pinobanksin ((2R,3R)-3,5,7-trihydroxy-2-phenyl-2,3-dihydrochromen4-one) and 3,4-dimethoxycinnamic acid (DMCA, (E)-3-(3,4-dimethoxyphenyl)prop-2-enoic acid). Caffeic acid phenethyl ester, BZC and CNC improved the cellular antioxidant capacity by reducing the malonaldehyde levels and increasing the SOD and glutathione peroxidase activities, reducing the intracellular calcium ion levels and preventing cell apoptosis [119]. Few studies concerning the effect of propolis on heart electrical activity are available, being rather centered on CAPE and pinocembrin. These compounds show cardioprotective effects in ischemia-reperfusion animal models-namely, decreasing the extension of the infarction, as well as preventing arrhythmias [121,141,142].

\subsection{Antioxidant and Anti-Inflammatory Activities}

The accessible information shows that, no matter its geographical origin and composition, propolis displays important antioxidant activities. In certain varieties, however, there seems to be a close relation between the antioxidant activity and the concentration of particular substances. For example, the antioxidant activity of Chinese red propolis is primarily attributed to CAPE [110], in Chilean propolis, it is mainly attributed to its phenylpropanoid content $[143,144]$ and, in Brazilian red propolis, it is ascribed to chalcones and isoflavonoids, including 7-O-methylvestitol (5-methoxy-2-([3S]-7methoxy-3,4-dihydro-2H-chromen-3-yl)phenol), medicarpin ((6aR,11aR)-9-methoxy-6a,11adihydro-6H-(1)benzofuro(3,2-c)chromen-3-ol) and 3,4,2', $3^{\prime}$-tetrahydrochalcone ((E)-1-(2,3dihydroxyphenyl)-3-(3,4-dihydroxyphenyl)prop-2-en-1-one) [17]. Moreover, in Brazilian red propolis, the total flavonoid content is associated with antioxidant activity, implying that all the phenolic and flavonoid substances present contribute to this activity [145]. In relation to this antioxidant impact, bioactive compounds in propolis affect many biochemical signaling pathways and, thus, physiological and pathological procedures. An antioxidant capacity is one of propolis' most significant properties [1]. Even though several experiments confirm the prospective antioxidant activity of propolis, no solid information is available on the safe dose in humans. Clinical studies using propolis and its biologically active compounds, including safety and bioavailability research, are therefore needed.

Besides the antioxidant activity observed in vitro for different propolis varieties, several in vivo studies have been performed in humans to assess the impact of propolis supplementation on the general antioxidation status. A commercially available propolis sample was administered for 30 days ( $48.75 \mathrm{mg}$ flavonoids/day) to a group of healthy subjects. In males, a transient decrease in malonaldehyde level was observed, together with an increase in SOD activity, while no effect was observed in females. These results suggest the possibility that propolis only has a transient and sex-dependent effect on serum lipid peroxidation [146].

Randomized clinical trials have been conducted in type 2 diabetes mellitus patients. A supplementation with Brazilian green propolis ( $900 \mathrm{mg} /$ day, 18 weeks) was associated with the increase of serum levels of GSH and total polyphenols and with the decrease of serum carbonyls (i.e., protein oxidation markers), as well as of lactate dehydrogenase activity [147]. The application of a propolis spray to diabetic foot ulcers (Beepolis ${ }^{\circledR}$ in $3 \%$ in propylene glycol, eight weeks or until cicatrization) was also associated with the increase of serum GSH levels, together with the decrease of TNF- $\alpha$ and IL-10 levels [148].

\section{Conclusions}

Propolis is a folk medicine with long-standing popularity. To the authors' knowledge, this is the first paper to provide a comprehensive review centered only on the cardiovascular effects of propolis, with the most recent literature having been considered. The reviewed studies affirm the interest of using propolis as a natural agent capable of counteracting the oxidative stress and inflammation that underlie several cardiovascular diseases, such as hypertension and atherosclerosis. Several varieties with cardiovascular effects were identified (see Table 6), with Brazilian green and red varieties showing the largest number 
of beneficial activities. Several factors are known to affect propolis composition, thus hindering the selection of a given variety for a specific purpose. Further research, especially preclinical, should be conducted to assess the cardiovascular benefits of given varieties with different compositions. Although most of the cardiovascular beneficial effects seem to result from the combined activities of many compounds acting through different signaling pathways, promising results have also been noted with several individual compounds that could integrate the current therapeutic arsenal. The possibility of using propolis as a food supplement should also be considered.

Table 6. Propolis activities according to their geographical origin (N.F.-not found and X-scientifically proven activity).

\begin{tabular}{|c|c|c|c|c|c|}
\hline Origin & $\begin{array}{c}\text { Endothelial and } \\
\text { Myocardial Protective }\end{array}$ & $\begin{array}{c}\text { Anti- } \\
\text { Hypertensive }\end{array}$ & $\begin{array}{l}\text { Anti- } \\
\text { Atherosclerotic }\end{array}$ & $\begin{array}{c}\text { Anti- } \\
\text { Hemostatic }\end{array}$ & $\begin{array}{c}\text { Anti- } \\
\text { Angiogenic }\end{array}$ \\
\hline Argentina & N.F. & N.F. & $X[149]$ & N.F. & N.F. \\
\hline Brazil (green propolis) & X [147] & N.F. & N.F. & N.F. & $X[111,112]$ \\
\hline Brazil (red propolis) & $X[17,145]$ & $X[88,92]$ & $X[67]$ & N.F. & N.F. \\
\hline Chile & $X[143]$ & $\mathrm{X}[93]$ & $X[65]$ & N.F. & $X[115]$ \\
\hline China & $X[69,119]$ & $X[99]$ & $X[67,70,71]$ & N.F. & N.F. \\
\hline China (red propolis) & $X[110]$ & N.F. & $\mathrm{X}[72]$ & NF & $X[110]$ \\
\hline Indonesia & N.F. & N.F. & N.F. & $X[82]$ & N.F. \\
\hline Korea & N.F. & N.F. & N.F. & N.F. & $X[117]$ \\
\hline Malaysia & $X[55]$ & N.F. & N.F. & $X[150]$ & N.F. \\
\hline Turkey & N.F. & $X[88,90]$ & N.F. & N.F. & N.F. \\
\hline
\end{tabular}

Author Contributions: Conceptualization, H.S. and A.R.; methodology, H.S. and A.R.; data curation, H.S. and A.R.; writing-original draft preparation, H.S., R.F., A.S., S.F., C.C. and A.R.; writingreview and editing, A.R. and H.S.; visualization, H.S., R.F., A.S., S.F., C.C. and A.R.; supervision, H.S. and A.R. and funding acquisition, H.S. and C.C. All authors have read and agreed to the published version of the manuscript.

Funding: This research received no external funding.

Institutional Review Board Statement: Not applicable.

Informed Consent Statement: Not applicable.

Conflicts of Interest: The authors declare no conflict of interest.

\section{References}

1. Daleprane, J.B.; Abdalla, D. Emerging Roles of Propolis: Antioxidant, Cardioprotective, and Antiangiogenic Actions. Evid. Based Complement. Altern. Med. 2013, 2013, 1-8. [CrossRef] [PubMed]

2. Pasupuleti, V.R.; Sammugam, L.; Ramesh, N.; Gan, S.H. Honey, Propolis, and Royal Jelly: A Comprehensive Review of Their Biological Actions and Health Benefits. Oxidative Med. Cell. Longev. 2017, 2017, 1-21. [CrossRef] [PubMed]

3. Greenaway, W.; Scaysbrook, T.; Whatley, F.R. The Composition and Plant Origins of Propolis: A Report of Work at Oxford. Bee World 1990, 71, 107-118. [CrossRef]

4. Silva-Carvalho, R.; Baltazar, F.; Almeida-Aguiar, C. Propolis: A Complex Natural Product with a Plethora of Biological Activities That Can Be Explored for Drug Development. Evid. Based Complement. Altern. Med. 2015, 2015, 1-29. [CrossRef]

5. Brown, R. Hive Products: Pollen, Propolis and Royal Jelly. Bee World 1989, 70, 109-117. [CrossRef]

6. Zabaiou, N.; Fouache, A.; Trousson, A.; Baron, S.; Zellagui, A.; Lahouel, M.; Lobaccaro, J.-M.A. Biological properties of propolis extracts: Something new from an ancient product. Chem. Phys. Lipids 2017, 207, 214-222. [CrossRef]

7. Oryan, A.; Alemzadeh, E.; Moshiri, A. Potential role of propolis in wound healing: Biological properties and therapeutic activities. Biomed. Pharmacother. 2018, 98, 469-483. [CrossRef]

8. El-Guendouz, S.; Aazza, S.; Lyoussi, B.; Bankova, V.; Lourenço, J.P.; Rosa Costa, A.M.; Mariano, J.F.; Miguel, M.G.; Faleiro, M.L. Impact of biohybrid magnetite nanoparticles and moroccan propolis on adherence of methicillin resistant strains of staphylococcus aureus. Molecules 2016, 21, 1208. [CrossRef]

9. Piccinelli, A.L.; Mencherini, T.; Celano, R.; Mouhoubi, Z.; Tamendjari, A.; Aquino, R.P.; Rastrelli, L. Chemical Composition and Antioxidant Activity of Algerian Propolis. J. Agric. Food Chem. 2013, 61, 5080-5088. [CrossRef]

10. Soltani, E.-K.; Cerezuela, R.; Charef, N.; Mezaache-Aichour, S.; Esteban, M.Á.; Zerroug, M.M. Algerian propolis extracts: Chemical composition, bactericidal activity and in vitro effects on gilthead seabream innate immune responses. Fish Shellfish. Immunol. 2017, 62, 57-67. [CrossRef] 
11. Salas, A.L.; Alberto, M.R.; Zampini, I.C.; Cuello, A.S.; Maldonado, L.; Ríos, J.L.; Schmeda-Hirschmann, G.; Isla, M.I. Biological activities of polyphenols-enriched propolis from Argentina arid regions. Phytomedicine 2016, 23, 27-31. [CrossRef] [PubMed]

12. Fangio, M.F.; Orallo, D.E.; Gende, L.B.; Churio, M.S. Chemical characterization and antimicrobial activity against Paenibacillus larvae of propolis from Buenos Aires province, Argentina. J. Apic. Res. 2019, 58, 626-638. [CrossRef]

13. Huang, S.; Zhang, C.; Wang, K.; Li, G.Q.; Hu, F.-L. Recent Advances in the Chemical Composition of Propolis. Molecules 2014, 19, 19610-19632. [CrossRef] [PubMed]

14. Trusheva, B.; Popova, M.; Bankova, V.; Simova, S.; Marcucci, M.C.; Miorin, P.L.; Pasin, F.D.R.; Tsvetkova, I. Bioactive Constituents of Brazilian Red Propolis. Evid. Based Complement. Altern. Med. 2006, 3, 249-254. [CrossRef] [PubMed]

15. Alencar, S.M.; Oldoni, T.L.C.; Castro, M.L.; Cabral, I.S.R.; Costa-Neto, C.M.; Cury, J.A.; Rosalen, P.; Ikegaki, M. Chemical composition and biological activity of a new type of Brazilian propolis: Red propolis. J. Ethnopharmacol. 2007, 113, 278-283. [CrossRef] [PubMed]

16. Bueno-Silva, B.B.; Rosalen, P.L.; Cury, J.A.; Ikegaki, M.; Souza, V.C.; Esteves, A.; De Alencar, S.M. Chemical Composition and Botanical Origin of Red Propolis, a New Type of Brazilian Propolis. Evid. Based Complement. Altern. Med. 2008, 5, 313-316. [CrossRef] [PubMed]

17. Righi, A.A.; Alves, T.R.; Negri, G.; Marques, L.M.; Breyer, H.; Salatino, A. Brazilian red propolis: Unreported substances, antioxidant and antimicrobial activities. J. Sci. Food Agric. 2011, 91, 2363-2370. [CrossRef]

18. Paviani, L.C.; Fiorito, G.; Sacoda, P.; Cabral, F.A. Different Solvents for Extraction of Brazilian Green Propolis: Composition and Extraction Yield of Phenolic Compounds. In Proceedings of the III Iberoamerican Conference on Supercritical Fluids Cartagena de Indias (Colombia), Cartagena de Indias, Colombia, 1-5 April 2013; pp. 1-7.

19. Quintino, R.L.; Reis, A.C.; Fernandes, C.C.; Martins, C.H.G.; Colli, A.C.; Crotti, A.E.M.; Squarisi, I.S.; Ribeiro, A.B.; Tavares, D.C.; Miranda, M.L.D. Brazilian Green Propolis: Chemical Compo-sition of Essential Oil and Their In Vitro Antioxidant, Antibacterial and Antiproliferative Activities. Braz. Arch. Biol. Technol. 2020, 63. [CrossRef]

20. de Menezes da Silveira, C.C.S.; Fernandes, L.M.P.; Silva, M.L.; Luz, D.A.; Gomes, A.R.Q.; Monteiro, M.C.; Machado, C.S.; Torres, Y.R.; de Lira, T.O.; Ferreira, A.G.; et al. Neurobehavioral and Antioxidant Effects of Ethanolic Extract of Yellow Propolis. Oxid. Med. Cell Longev. 2016, 2016. [CrossRef]

21. Machado, C.S.; Mokochinski, J.B.; De Lira, T.O.; Oliveira, F.D.C.E.D.; Cardoso, M.V.; Ferreira, R.G.; Sawaya, A.C.H.F.; Ferreira, A.G.; Pessoa, C.; Cuesta-Rubio, O.; et al. Comparative Study of Chemical Composition and Biological Activity of Yellow, Green, Brown, and Red Brazilian Propolis. Evid. Based Complement. Altern. Med. 2016, 2016, 1-11. [CrossRef]

22. Fernandes, F.H.; Guterres, Z.D.R.; Violante, I.M.P.; Lopes, T.F.S.; Garcez, W.S.; Garcez, F.R. Evaluation of mutagenic and antimicrobial properties of brown propolis essential oil from the Brazilian Cerrado biome. Toxicol. Rep. 2015, 2, 1482-1488. [CrossRef] [PubMed]

23. De Lima, V.H.M.; Almeida, K.D.C.R.; Alves, C.C.F.; Rodrigues, M.L.; Crotti, A.E.M.; De Souza, J.M.; Ribeiro, A.B.; Squarisi, I.S.; Tavares, D.C.; Martins, C.H.; et al. Biological properties of volatile oil from Brazilian brown propolis. Rev. Bras. Farm. 2019, 29, 807-810. [CrossRef]

24. Papachroni, D.; Graikou, K.; Kosalec, I.; Damianakos, H.; Ingram, V.; Chinou, I. Phytochemical Analysis and Biological Evaluation of Selected African Propolis Samples from Cameroon and Congo. Nat. Prod. Commun. 2015, 10, 67-70. [CrossRef] [PubMed]

25. Montenegro, G.; Peña, R.C.; Avila, G.; Timmerman, B.N. Botanial origin and seasonal production hives of central Chile. Bol. Bot. Univ. Sāo Paulo. 2001, 19, 1-6. [CrossRef]

26. Muñoz, O.; Peña, R.C.; Ureta, E.; Montenegro, G.; Caldwell, C.; Timmermann, B.N. Phenolic Compounds of Propolis from Central Chilean Matorral. Z. Nat. C 2001, 56, 273-277. [CrossRef] [PubMed]

27. Miguel, M.G.; Antunes, M.D. Is propolis safe as an alternative medicine? J. Pharm. Bioallied Sci. 2011, 3, 479-495. [CrossRef] [PubMed]

28. Graikou, K.; Popova, M.; Gortzi, O.; Bankova, V.; Chinou, I. Characterization and biological evaluation of selected Mediterranean propolis samples. Is it a new type? LWT Food Sci. Technol. 2016, 65, 261-267. [CrossRef]

29. Bankova, V. Recent trends and important developments in propolis research. Evid. Based Complement. Altern. Med. 2005, 2, 29-32. [CrossRef]

30. Hegazi, A.G.; El-Hady, F.K.A. Egyptian propolis: 3. Antioxidant, antimicrobial activities and chemical composition of propolis from reclaimed lands. Z. Nat. C 2002, 57, 395-402. [CrossRef]

31. Rushdi, A.I.; Adgaba, N.; Bayaqoob, N.I.M.; Al-Ghamdi, A.; Simoneit, B.R.T.; El-Mubarak, A.H.; Al-Mutlaq, K.F. Characteristics and chemical compositions of propolis from Ethiopia. SpringerPlus 2014, 3, 1-9. [CrossRef]

32. Velikova, M.; Bankova, V.; Sorkun, K.; Houcine, S.; Tsvetkova, I.; Kujumgiev, A. Propolis from the Mediterranean region: Chemical composition and antimicrobial activity. Z. Nat. C 2000, 55, 790-793. [CrossRef] [PubMed]

33. Bankova, V.; Popova, M.; Bogdanov, S.; Sabatini, A.-G. Chemical composition of European propolis: Expected and unexpected results. Z. Nat. C 2002, 57, 530-533. [CrossRef] [PubMed]

34. Melliou, E.; Chinou, I. Chemical Analysis and Antimicrobial Activity of Greek Propolis. Planta Med. 2004, 70, 515-519. [CrossRef] [PubMed]

35. Banskota, A.H.; Tezuka, Y.; Kadota, S. Recent progress in pharmacological research of propolis. Phytother. Res. 2001, 15, 561-571. [CrossRef] 
36. Petrova, A.; Popova, M.; Kuzmanova, C.; Tsvetkova, I.; Naydenski, H.; Muli, E.; Bankova, V. New biologically active compounds from Kenyan propolis. Fitoterapia 2010, 81, 509-514. [CrossRef]

37. Popova, M.; Trusheva, B.; Antonov, D.; Cutajar, S.; Mifsud, D.; Farrugia, C.; Tsvetkova, I.; Najdenski, H.; Bankova, V. The specific chemical profile of Mediterranean propolis from Malta. Food Chem. 2011, 126, 1431-1435. [CrossRef]

38. Toreti, V.C.; Sato, H.H.; Pastore, G.M.; Park, Y.K. Recent Progress of Propolis for Its Biological and Chemical Compositions and Its Botanical Origin. Evid. Based Complement. Altern. Med. 2013, 2013, 1-13. [CrossRef]

39. Siheri, W.; Zhang, T.; Ebiloma, G.U.; Biddau, M.; Woods, N.; Hussain, M.Y.; Clements, C.J.; Fearnley, J.; Ebel, R.E.; Paget, T.; et al. Chemical and Antimicrobial Profiling of Propolis from Different Regions within Libya. PLoS ONE 2016, 11, e0155355. [CrossRef]

40. Siheri, W.; Igoli, J.O.; Gray, A.I.; Nasciemento, T.G.; Zhang, T.; Fearnley, J.; Clements, C.J.; Carter, K.C.; Carruthers, J.; Edrada-Ebel, R.; et al. The Isolation of Antiprotozoal Compounds from Libyan Propolis. Phytother. Res. 2014, 28, 1756-1760. [CrossRef]

41. Martinotti, S.; Ranzato, E. Propolis: A new frontier for wound healing? Burn. Trauma 2015, 3, 1-7. [CrossRef]

42. Popova, M.; Lyoussi, B.; Aazza, S.; Antunes, D.; Bankova, V.; Miguel, G. Antioxidant and $\alpha$-Glucosidase Inhibitory Properties and Chemical Profiles of Moroccan Propolis. Nat. Prod. Commun. 2015, 10, 1961-1964. [CrossRef] [PubMed]

43. Miguel, M.G. Chemical and biological properties of propolis from the western countries of the Mediterranean basin and Portugal. Int. J. Pharm. Pharm. Sci. 2013, 5, 403-409.

44. Inui, S.; Hosoya, T.; Shimamura, Y.; Masuda, S.; Ogawa, T.; Kobayashi, H.; Shirafuji, K.; Moli, R.T.; Kozone, I.; Shin-Ya, K.; et al. Solophenols B-D and Solomonin: New Prenylated Polyphenols Isolated from Propolis Collected from The Solomon Islands and Their Antibacterial Activity. J. Agric. Food Chem. 2012, 60, 11765-11770. [CrossRef] [PubMed]

45. Popova, M.; Silici, S.; Kaftanoglu, O.; Bankova, V. Antibacterial activity of Turkish propolis and its qualitative and quantitative chemical composition. Phytomedicine 2005, 12, 221-228. [CrossRef]

46. Doganli, G.A. Phenolic Content and Antibiofilm Activity of Propolis Against Clinical MSSA Strains. Rec. Nat. Prod. 2016, 5, 617-627.

47. Ghisalberti, E.L. Propolis: A Review. BEE World 1979, 60, 59-84. [CrossRef]

48. Sung, S.-H.; Choi, G.-H.; Lee, N.-W.; Shin, B.-C. External Use of Propolis for Oral, Skin, and Genital Diseases: A Systematic Review and Meta-Analysis. Evid. Based Complement. Altern. Med. 2017, 2017, 1-10. [CrossRef]

49. Yang, W.; Wu, Z.; Huang, Z.Y.; Miao, X. Preservation of orange juice using propolis. J. Food Sci. Technol. 2017, 54, 3375-3383. [CrossRef]

50. Pileggi, R.; Antony, K.; Johnson, K.; Zuo, J.; Holliday, L.S. Propolis inhibits osteoclast maturation. Dent. Traumatol. 2009, 25, 584-588. [CrossRef]

51. Fokt, H.; Pereira, A.; Ferreira, A.M.; Cunha, A.; Aguiar, C. How do bees prevent hive infections? The antimicrobial properties of propolis. Appl Microbiol. 2010, 1, 481-493.

52. Helfenberg, K.D. The analysis of beeswax and propolis. Chem Zeitungm. 1908, 31, 987-998.

53. Anjum, S.I.; Ullah, A.; Khan, K.A.; Attaullah, M.; Khan, H.; Ali, H.; Bashir, M.A.; Tahir, M.; Ansari, M.J.; Ghramh, H.A.; et al. Composition and functional properties of propolis (bee glue): A review. Saudi J. Biol. Sci. 2019, 26, 1695-1703. [CrossRef] [PubMed]

54. Dobrowolski, J.W.; Vohora, S.B.; Sharma, K.; Shah, S.A.; Naqvi, S.A.H.; Dandiya, P.C. Antibacterial, antifungal, antiamoebic, anti-inflammatory and antipyretic studies on propolis bee products. J. Ethnopharmacol. 1991, 35, 77-82. [CrossRef]

55. Ahmed, R.; Tanvir, E.M.; Hossen, S.; Afroz, R.; Ahmmed, I.; Rumpa, N.-E.-N.; Paul, S.; Gan, S.H.; Sulaiman, S.A.; Khalil, I. Antioxidant Properties and Cardioprotective Mechanism of Malaysian Propolis in Rats. Evid.-Based Complement. Altern. Med. 2017, 2017, 1-11. [CrossRef] [PubMed]

56. Hegazi, A.G.; El Hady, F.K.A.; Allah, F.A.A. Chemical composition and antimicrobial activity of European propolis. Z. Nat. C 2000, 55, 70-75. [CrossRef]

57. Kim, J.D.; Liu, L.; Guo, W.; Meydani, M. Chemical structure of flavonols in relation to modulation of angiogenesis and im-muneendothelial cell adhesion. J. Nutr. Biochem. 2006, 17, 165-176. [CrossRef]

58. Benjamin, E.J.; Blaha, M.J.; Chiuve, S.E.; Cushman, M.; Das, S.R.; Deo, R.; De Ferranti, S.D.; Floyd, J.; Fornage, M.; Gillespie, C.; et al. Heart Disease and Stroke Statistics-2017 Update: A Report From the American Heart Association. Circulation 2017, 135, e146-e603. [CrossRef]

59. Dalia, G.; King, R. Burden of cardiovascular disease (CVD) on economic cost. Comparison of outcomes in US and Europe. Circ. Cardiovasc. Qual. Outcomes 2017, 10, A207.

60. Shad, B.; Ashouri, A.; Hasandokht, T.; Rajati, F.; Salari, A.; Naghshbandi, M.; Mirbolouk, F. Effect of multimorbidity on quality of life in adult with cardiovascular disease: A cross-sectional study. Health Qual. Life Outcomes 2017, 15, 1-8. [CrossRef]

61. Hald, K.; Larsen, F.B.; Nielsen, K.M.; Meillier, L.K.; Johansen, M.B.; Larsen, M.L.; Christensen, B.; Nielsen, C.V. Medication adherence, biological and lifestyle risk factors in patients with myocardial infarction: A ten-year follow-up on socially differentiated cardiac rehabilitation. Scand. J. Prim. Health Care 2019, 37, 182-190. [CrossRef] [PubMed]

62. Bergheanu, S.C.; Bodde, M.C.; Jukema, J.W. Pathophysiology and treatment of atherosclerosis: Current view and future perspective on lipoprotein modification treatment. Neth. Heart J. 2017, 25, 231-242. [CrossRef] [PubMed]

63. Xuan, H.; Li, Z.; Wang, J.; Wang, K.; Fu, C.; Yuan, J.; Hu, F. Propolis Reduces Phosphatidylcholine-Specific Phospholipase C Activity and Increases Annexin a7 Level in Oxidized-LDL-Stimulated Human Umbilical Vein Endothelial Cells. Evid. Based Complement. Altern. Med. 2014, 2014, 1-9. [CrossRef] [PubMed] 
64. Tian, H.; Sun, H.-W.; Zhang, J.-J.; Zhang, X.-W.; Zhao, L.; Guo, S.; Li, Y.-Y.; Jiao, P.; Wang, H.; Shucun, Q.; et al. Ethanol extract of propolis protects macrophages from oxidized low density lipoprotein-induced apoptosis by inhibiting CD36 expression and endoplasmic reticulum stress-C/EBP homologous protein pathway. BMC Complement. Altern. Med. 2015, 15, 230. [CrossRef] [PubMed]

65. Saavedra, N.; Cuevas, A.; Cavalcante, M.F.; Dörr, F.A.; Saavedra, K.; Zambrano, T.; Abdalla, D.S.P.; Salazar, L.A. Polyphenols from Chilean Propolis and Pinocembrin Reduce MMP-9 Gene Expression and Activity in Activated Macrophages. BioMed Res. Int. 2016, 2016, 1-8. [CrossRef]

66. Li, Y.; Chen, M.; Xuan, H.; Hu, F. Effects of Encapsulated Propolis on Blood Glycemic Control, Lipid Metabolism, and Insulin Resistance in Type 2 Diabetes Mellitus Rats. Evid. Based Complement. Altern. Med. 2011, 2012, 1-8. [CrossRef]

67. Daleprane, J.B.; da Silva Freitas, V.; Pacheco, A.; Rudnicki, M.; Faine, L.A.; Dörr, F.A.; Ikegaki, M.; Salazar, L.A.; Ong, T.P.; Abdalla, D. Anti-atherogenic and anti-angiogenic activities of polyphenols from propolis. J. Nutr. Biochem. 2012, 23, 557-566. [CrossRef]

68. El-Sayed 9, A.; Ammar Algridi, M.; Mohammed Lashkham, N. Hypolipidemic and Antiatherogenic Effects of Aqueous Extract of Libyan Propolis in Lead Acetate Intoxicated Male Albino Mice. Int. J. Sci. Res. 2013, 14, 2319-7064.

69. Fang, Y.; Li, J.; Ding, M.; Xu, X.; Zhang, J.; Jiao, P.; Han, P.; Wang, J.; Yao, S. Ethanol extract of propolis protects endothelial cells from oxidized low density lipoprotein-induced injury by inhibiting lectin-like oxidized low density lipoprotein receptor-1mediated oxidative stress. Exp. Biol. Med. 2014, 239, 1678-1687. [CrossRef]

70. Oršolić, N.; Jurčević, I.L.; Đikić, D.; Rogić, D.; Odeh, D.; Balta, V.; Junaković, E.P.; Terzić, S.; Jutrić, D. Effect of Propolis on Diet-induced hyperlipidemia and atherogenic indices in mice. Antioxidants 2019, 8, 156. [CrossRef]

71. Tolba, M.F.; Azab, S.S.; Khalifa, A.E.; Abdel-Rahman, S.Z.; Abdel-Naim, A.B. Caffeic acid phenethyl ester, a promising component of propolis with a plethora of biological activities: A review on its anti-inflammatory, neuroprotective, hepatoprotective, and cardioprotective effects. IUBMB Life 2013, 65, 699-709. [CrossRef] [PubMed]

72. Yu, Y.; Si, Y.; Song, G.; Luo, T.; Wang, J.; Qin, S. Ethanolic extract of propolis promotes reverse cholesterol transport and the ex-pression of ATP-binding cassette transporter A1 and G1 in mice. Lipids 2011, 46, 805-811. [CrossRef] [PubMed]

73. Nishikawa, S.; Aoyama, H.; Kamiya, M.; Higuchi, J.; Kato, A.; Soga, M.; Kawai, T.; Yoshimura, K.; Kumazawa, S.; Tsuda, T. Artepillin C, a typical brazilian propolis-derived component, induces brown-like adipocyte formation in C3H10T1/2 cells, primary inguinal white adipose tissue-derived adipocytes, and mice. PLoS ONE 2016, 11, 1-12. [CrossRef] [PubMed]

74. Yang, H.; Dong, Y.; Du, H.; Shi, H.; Peng, Y.; Li, X. Antioxidant Compounds from Propolis Collected in Anhui, China. Molecules 2011, 16, 3444-3455. [CrossRef]

75. Gough, P.J.; Gomez, I.G.; Wille, P.T.; Raines, E.W. Macrophage expression of active MMP-9 induces acute plaque disruption in ap-oE-deficient mice. J. Clin. Investig. 2005, 116, 59-69. [CrossRef]

76. Loftus, I.M.; Naylor, A.R.; Goodall, S.; Crowther, M.; Jones, L.; Bell, P.R.F.; Thompson, M.M. Increased Matrix Metalloproteinase-9 Activity in Unstable Carotid Plaques. Stroke 2000, 31, 40-47. [CrossRef]

77. Versteeg, H.H.; Heemskerk, J.W.M.; Levi, M.; Reitsma, P.H. New Fundamentals in Hemostasis. Physiol. Rev. 2013, 93, 327-358 [CrossRef]

78. Xu, X.R.; Zhang, D.; Oswald, B.E.; Carrim, N.; Wang, X.; Hou, Y.; Zhang, Q.; LaValle, C.; McKeown, T.; Marshall, A.H.; et al. Platelets are versatile cells: New discoveries in hemostasis, thrombosis, immune responses, tumor metastasis and beyond. Crit. Rev. Clin. Lab. Sci. 2016, 53, 409-430. [CrossRef]

79. Ohkura, N.; Takata, Y.; Ando, K.; Kanai, S.; Watanabe, E.; Nohira, T.; Atsumi, G.-I. Propolis and its constituent chrysin inhibit plasminogen activator inhibitor 1 production induced by tumour necrosis factor- $\alpha$ and lipopolysaccharide. J. Apic. Res. 2012, 51, 179-184. [CrossRef]

80. Ohkura, N.; Oishi, K.; Kihara-Negishi, F.; Atsumi, G.I.; Tatefuji, T. Effects of a diet containing Brazilian propolis on lipopolysaccharideinduced increases in plasma plasminogen activator inhibitor-1 levels in mice. J. Intercult. Ethnopharmacol. 2016, 5, 439-443. [CrossRef]

81. Bojić, M.; Antolić, A.; Tomičić, M.; Debeljak, Ž.; Maleš, Ž. Propolis ethanolic extracts reduce adenosine diphosphate induced platelet aggregation determined on whole blood. Nutr. J. 2018, 17, 1-8. [CrossRef]

82. Martina, S.J.; Luthfi, M.; Govindan, P.; Wahyuni, A.S. Effectivity comparison between aspirin, propolis, and bee pollen as an antiplatelet based on bleeding time taken on mice. MATEC Web. Conf. 2018, 197, 1-7. [CrossRef]

83. Zhang, Y.; Yang, T.-T.; Xia, L.; Zhang, W.-F.; Wang, J.-F.; Wu, Y.-P. Inhibitory Effect of Propolis on Platelet Aggregation In Vitro. J. Healthc. Eng. 2017, 2017, 1-6. [CrossRef] [PubMed]

84. Liu, G.; Xie, W.; He, A.; Da, X.; Liang, M.; Yao, G.; Xiang, J.; Gao, C.; Ming, Z. Antiplatelet activity of chrysin via inhibiting platelet $\alpha \mathrm{IIb} \beta 3$-mediated signaling pathway. Mol. Nutr. Food Res. 2016, 60, 1984-1993. [CrossRef] [PubMed]

85. Hsiao, G.; Lee, J.J.; Lin, K.H.; Shen, C.H.; Fong, T.H.; Chou, D.S.; Sheu, J.R. Characterization of a novel and potent collagen antagonist, caffeic acid phenethyl ester, in human platelets: In vitro and in vivo studies. Cardiovasc. Res. 2007, 75, 782-792. [CrossRef] [PubMed]

86. Akbay, E.; Özenirler, Ç.; Çelemli, Ö.G.; Durukan, A.B.; Onur, M.A.; Sorkun, K. Effects of propolis on warfarin efficacy. Kardiochir. Torakochir. Pol. 2017, 14, 43-46. [CrossRef]

87. Schmieder, R.E. Hypertoniebedingte endorganschäden. Dtsch. Arztebl. 2010, 107, 866-873. 
88. Silveira, M.A.D.; Teles, F.; Berretta, A.A.; Sanches, T.R.; Rodrigues, C.E.; Seguro, A.C.; Andrade, L. Effects of Brazilian green propolis on proteinuria and renal function in patients with chronic kidney disease: A randomized, double-blind, placebocontrolled trial. BMC Nephrol. 2019, 20,1-12. [CrossRef]

89. Kubota, Y.; Umegaki, K.; Kobayashi, K.; Tanaka, N.; Kagota, S.; Nakamura, K.; Kunitomo, M.; Shinozuka, K. Anti-hypertensive effects of brazilian propolis in spontaneously hypertensive rats. Clin. Exp. Pharmacol. Physiol. 2004, 31, S29-S30. [CrossRef]

90. Gogebakan, A.; Talas, Z.S.; Özdemir, I.; Sahna, E. Role of Propolis on Tyrosine Hydroxylase Activity and Blood Pressure in Nitric Oxide Synthase-Inhibited Hypertensive Rats. Clin. Exp. Hypertens. 2012, 34, 424-428. [CrossRef]

91. Aoi, W.; Hosogi, S.; Niisato, N.; Yokoyama, N.; Hayata, H.; Miyazaki, H.; Kusuzaki, K.; Fukuda, T.; Fukui, M.; Nakamura, N.; et al. Improvement of insulin resistance, blood pressure and interstitial $\mathrm{pH}$ in early developmental stage of insulin resistance in OLETF rats by intake of propolis extracts. Biochem. Biophys. Res. Commun. 2013, 432, 650-653. [CrossRef]

92. Teles, F.; Da Silva, T.M.; Da Cruz, F.P.; Honorato, V.H.; De Oliveira Costa, H.; Barbosa, A.P.F.; de Oliveira, S.G.; Porfírio, Z.; Libório, A.B.; Borges, R.L.; et al. Brazilian red propolis attenuates hypertension and renal damage in 5/6 renal ablation model. PLoS ONE 2015, 10, 1-15. [CrossRef] [PubMed]

93. Mujica, V.; Orrego, R.; Pérez, J.; Romero, P.; Ovalle, P.; Zúñiga-Hernández, J.; Arredondo, M.; Leiva, E. The Role of Propolis in Oxidative Stress and Lipid Metabolism: A Randomized Controlled Trial. Evid. Based Complement. Altern. Med. 2017, $2017,1-11$. [CrossRef] [PubMed]

94. Selamoglu Talas, Z. Propolis reduces oxidative stress in l-NAME-induced hypertension rats. Cell Biochem. Funct. 2014, 32, 150-154. [CrossRef] [PubMed]

95. Silva, V.; Genta, G.; Möller, M.N.; Masner, M.; Thomson, L.; Romero, N.; Radi, R.; Fernandes, D.C.; Laurindo, F.R.M.; Heinzen, H.; et al. Antioxidant Activity of Uruguayan Propolis. In Vitro and Cellular Assays. J. Agric. Food Chem. 2011, 59, 6430-6437. [CrossRef] [PubMed]

96. Salmas, R.E.; Gulhan, M.F.; Durdagi, S.; Sahna, E.; Abdullah, H.I.; Selamoglu, Z. Effects of propolis, caffeic acid phenethyl ester, and pollen on renal injury in hypertensive rat: An experimental and theoretical approach. Cell Biochem. Funct. 2017, 35, 304-314. [CrossRef]

97. Zhou, H.; Wang, H.; Shi, N.; Wu, F. Potential Protective Effects of the Water-Soluble Chinese Propolis on Hypertension Induced by High-Salt Intake. Clin. Transl. Sci. 2020, 2020, 907-915. [CrossRef]

98. Mishima, S.; Yoshida, C.; Akino, S.; Sakamoto, T. Antihypertensive Effects of Brazilian Propolis: Identification of Caffeoylquinic Acids as Constituents Involved in the Hypotension in Spontaneously Hypertensive Rats. Biol. Pharm. Bull. 2005, 28, 1909-1914. [CrossRef]

99. Sun, Y.; Han, M.; Shen, Z.; Huang, H.; Miao, X. Anti-hypertensive and cardioprotective effects of a novel apitherapy formulation via upregulation of peroxisome proliferator-activated receptor- $\alpha$ and $-\gamma$ in spontaneous hypertensive rats. Saudi J. Biol. Sci. 2018, 25, 213-219. [CrossRef]

100. Khalaf, D.A.; Thanoon, I.A.-J. Effects of Bee Propolis on Blood Pressure Record and Certain Biochemical Parameter in Healthy Volunteers. Ann. Coll. Med. Mosul 2018, 40, 20-26.

101. Maruyama, H.; Sumitou, Y.; Sakamoto, T.; Araki, Y.; Hara, H. Antihypertensive effects of flavonoids isolated from brazilian green propolis in spontaneously hypertensive rats. Biol. Pharm. Bull. 2009, 32, 1244-1250. [CrossRef]

102. Silva, H.; Lopes, N.M.F. Cardiovascular Effects of Caffeic Acid and Its Derivatives: A Comprehensive Review. Front Physiol. 2020, 11, 1-20. [CrossRef] [PubMed]

103. Malarvili, T.; Veerappan, R. Effects of chrysin on free radicals and enzymatic antioxidants in $\mathrm{N}^{\omega}$-nitro-l-arginine methyl ester: Induced hypertensive rats. Int. J. Nutr. Pharmacol. Neurol. Dis. 2014, 4, 112. [CrossRef]

104. Veerappan, R.; Malarvili, T. Chrysin Pretreatment Improves Angiotensin System, cGMP Concentration in L-NAME Induced Hypertensive Rats. Indian J. Clin. Biochem. 2019, 34, 288-295. [CrossRef] [PubMed]

105. Tahergorabi, Z.; Khazaei, M. A Review on Angiogenesis and Its Assays. Iran J. Basic Med. Sci. 2012, 15, $1110-1126$.

106. Potente, M.; Carmeliet, P. The Link between Angiogenesis and Endothelial Metabolism. Annu. Rev. Physiol. 2017, 79, 43-66. [CrossRef]

107. Carmeliet, P. Angiogenesis in life, disease and medicine. Nature 2005, 438, 932-936. [CrossRef]

108. Ucuzian, A.A.; Gassman, A.A.; East, A.T.; Greisler, P.J. Molecular mediators of angiogenesis. J. Burn Care Res. $2010,31,158-175$. [CrossRef]

109. Camaré, C.; Pucelle, M.; Nègre-Salvayre, A.; Salvayre, R. Angiogenesis in the atherosclerotic plaque. Redox Biol. 2017, 12, 18-34. [CrossRef]

110. Izuta, H.; Shimazawa, M.; Tsuruma, K.; Araki, Y.; Mishima, S.; Hara, H. Bee products prevent VEGF-induced angiogenesis in human umbilical vein endothelial cells. BMC Complement. Altern. Med. 2009, 9, 45. [CrossRef]

111. Chikaraishi, Y.; Izuta, H.; Shimazawa, M.; Mishima, S.; Hara, H. Angiostatic effects of Brazilian green propolis and its chemical constituents. Mol. Nutr. Food Res. 2010, 54, 566-575. [CrossRef]

112. Kunimasa, K.; Ahn, M.R.; Kobayashi, T.; Eguchi, R.; Kumazawa, S.; Fujimori, Y.; Nakano, T.; Nakayama, T.; Kaji, K.; Ohta, T. Brazilian propolis suppresses angiogenesis by inducing apoptosis in tube-forming endothelial cells through inactivation of survival signal ERK1/2. Evid. Based Complement. Altern. Med. 2011, 2011. [CrossRef] [PubMed] 
113. Meneghelli, C.; Joaquim, L.S.D.; Félix, G.L.Q.; Somensi, A.; Tomazzoli, M.; Da Silva, D.A.; Berti, F.V.; Veleirinho, M.B.R.; Recouvreux, D.D.O.S.; Zeri, A.C.; et al. Southern Brazilian autumnal propolis shows anti-angiogenic activity: An in vitro and in vivo study. Microvasc. Res. 2013, 88, 1-11. [CrossRef] [PubMed]

114. Cuevas, A.; Saavedra, N.; Cavalcante, M.F.; Salazar, L.A.; Abdalla, D. Identification of microRNAs involved in the modulation of pro-angiogenic factors in atherosclerosis by a polyphenol-rich extract from propolis. Arch. Biochem. Biophys. 2014, 557, 28-35. [CrossRef] [PubMed]

115. Cuevas, A.; Saavedra, N.; Rudnicki, M.; Abdalla, D.S.P.; Salazar, L.A. ERK1/2 and HIF1 Are Involved in Antiangiogenic Effect of Polyphenols-Enriched Fraction from Chilean Propolis. Evid. Based Complement. Altern. Med. 2015, 2015. [CrossRef]

116. Daleprane, J.B.; Schmid, T.; Dehne, N.; Rudnicki, M.; Menrad, H.; Geis, T.; Ikegaki, M.; Ong, T.P.; Brüne, B.; Abdalla, D.S.P. Suppression of Hypoxia-Inducible Factor- $1 \alpha$ Contributes to the Antiangiogenic Activity of Red Propolis Polyphenols in Human Endothelial Cells. J. Nutr. 2012, 142, 441-447. [CrossRef]

117. Park, S.I.; Ohta, T.; Kumazawa, S.; Jun, M.; Ahn, M.R. Korean propolis suppresses angiogenesis through inhibition of tube for-mation and endothelial cell proliferation. Nat. Prod. Commun. 2014, 9, 555-560.

118. Rajesh, K.G.; Surekha, R.H.; Mrudula, S.K.; Prasad, Y.; Sanjib, K.S.; Prathiba, N. Oxidative and nitrosative stress in association with DNA damage in coronary heart disease. Singap. Med. J. 2011, 52, 283-288.

119. Sun, L.; Wang, K.; Xu, X.; Ge, M.; Hu, F.-L.; Hu, F.-L. Potential Protective Effects of Bioactive Constituents from Chinese Propolis against Acute Oxidative Stress Induced by Hydrogen Peroxide in Cardiac H9c2 Cells. Evid. Based Complement. Altern. Med. 2017, 2017, 1-10. [CrossRef]

120. Ince, H.; Kandemir, E.; Bagci, C.; Gulec, M.; Akyol, O. The effect of caffeic acid phenethyl ester on short-term acute myocardial ischemia. Med. Sci. Monit. 2006, 12, BR187-BR193.

121. Ozer, M.K.; Parlakpinar, H.; Acet, A. Reduction of ischemia-reperfusion induced myocardial infarct size in rats by caffeic acid phenethyl ester (CAPE). Clin. Biochem. 2004, 37, 702-705. [CrossRef]

122. Dianat, M.; Saadatfard, S.; Badavi, M.; Pour, A.A.; Sadeghi, N. Corrigendum: The effect of caffeic acid phenethyl ester on devel-opment of left ventricular dysfunction in cirrhotic rats. Int. Cardiovasc. Res. J. 2018, 12, 159.

123. Ahn, M.-R.; Kunimasa, K.; Kumazawa, S.; Nakayama, T.; Kaji, K.; Uto, Y.; Hori, H.; Nagasawa, H.; Ohta, T. Correlation between antiangiogenic activity and antioxidant activity of various components from propolis. Mol. Nutr. Food Res. 2009, 53, 643-651. [CrossRef] [PubMed]

124. Khaddaj Mallat, R.; Mathew John, C.; Kendrick, D.J.; Braun, A.P. The vascular endothelium: A regulator of arterial tone and in-terface for the immune system. Crit. Rev. Clin. Lab. Sci. 2017, 54, 458-470. [CrossRef] [PubMed]

125. Deanfield, J.E.; Halcox, J.P.; Rabelink, T.J. Endothelial function and dysfunction: Testing and clinical relevance. Circulation 2007, 115, 1285-1295. [CrossRef] [PubMed]

126. Mathews, M.T.; Berk, B.C. PARP-1 inhibition prevents oxidative and nitrosative stress-induced endothelial cell death via trans-activation of the VEGF receptor 2. Arterioscler. Thromb. Vasc. Biol. 2008, 28, 711-717. [CrossRef]

127. Liaudet, L.; Vassalli, G.; Pacher, P. Role of peroxynitrite in the redox regulation of cell signal transduction pathways. Front. Biosci. 2009, 14, 4809-4814. [CrossRef]

128. Dharmashankar, K.; Widlansky, M.E. Vascular endothelial function and hypertension: Insights and directions. Curr. Hypertens Rep. 2010, 12, 448-455. [CrossRef]

129. Toda, N.; Nakanishi-Toda, M. How mental stress affects endothelial function. Pflügers Archiv-Eur. J. Physiol. 2011, 462, 779-794. [CrossRef]

130. Herrera, M.D.; Mingorance, C.; Rodríguez-Rodríguez, R.; Alvarez de Sotomayor, M. Endothelial dysfunction and aging: An update. Aging Res. Rev. 2010, 9, 142-152. [CrossRef]

131. Soultati, A.; Mountzios, G.; Avgerinou, C.; Papaxoinis, G.; Pectasides, D.; Dimopoulos, M.-A.; Papadimitriou, C. Endothelial vascular toxicity from chemotherapeutic agents: Preclinical evidence and clinical implications. Cancer Treat. Rev. 2012, 38, 473-483. [CrossRef]

132. Widmer, R.J.; Lerman, A. Endothelial dysfunction and cardiovascular diseases. Glob. Cardiol. Sci. Pract. 2014, 3, 291-308. [CrossRef] [PubMed]

133. Sawamura, T.; Kume, N.; Aoyama, T.; Moriwaki, H.; Hoshikawa, H.; Aiba, Y.; Tanaka, T.; Miwa, S.; Katsura, Y.; Kita, T.; et al. LOX-1 colning and antibody. Nature 1997, 386, 73-77. [CrossRef] [PubMed]

134. Chang, H.; Yuan, W.; Wu, H.; Yin, X.; Xuan, H. Bioactive components and mechanisms of Chinese poplar propolis alleviates oxidized low-density lipoprotein-induced endothelial cells injury. BMC Complement. Altern. Med. 2018, 18, 142. [CrossRef] [PubMed]

135. Xuan, H.; Yuan, W.; Chang, H.; Liu, M.; Hu, F. Anti-inflammatory effects of Chinese propolis in lipopolysaccharide-stimulated human umbilical vein endothelial cells by suppressing autophagy and MAPK/NF- $\mathrm{B}$ signaling pathway. Inflammopharmacology 2019, 27, 561-571. [CrossRef]

136. Díaz-flores, M.; Baiza-gutman, L.A. Biochemical Mechanisms of Vascular Complications in Diabetes. In The Diabetes Textbook; Springer: Cham, Switzerland, 2019; pp. 695-707.

137. El-Awady, M.S.; El-Agamy, D.S.; Suddek, G.M.; Nader, M.A. Propolis protects against high glucose-induced vascular endothelial dysfunction in isolated rat aorta. J. Physiol. Biochem. 2014, 70, 247-254. [CrossRef] 
138. Gould, N.; Doulias, P.-T.; Tenopoulou, M.; Raju, K.; Ischiropoulos, H. Regulation of Protein Function and Signaling by Reversible CysteineS-Nitrosylation. J. Biol. Chem. 2013, 288, 26473-26479. [CrossRef]

139. Pacher, P.; Schulz, R.; Liaudet, L.; Szabó, C. Nitrosative stress and pharmacological modulation of heart failure. Trends Pharmacol. Sci. 2005, 26, 302-310. [CrossRef]

140. Schiattarella, G.G.; Altamirano, F.; Tong, D.; French, K.M.; Villalobos, E.; Kim, S.Y.; Luo, X.; Jiang, N.; May, H.I.; Wang, Z.V.; et al. Nitrosative stress drives heart failure with preserved ejection fraction. Nature 2019, 568, 351-356. [CrossRef]

141. Huang, S.-S.; Liu, S.; Lin, S.-M.; Liao, P.-H.; Lin, R.-H.; Chen, Y.-C.; Chih, C.-L.; Tsai, S.-K. Antiarrhythmic effect of caffeic acid phenethyl ester (CAPE) on myocardial ischemia/reperfusion injury in rats. Clin. Biochem. 2005, 38, 943-947. [CrossRef]

142. Lungkaphin, A.; Pongchaidecha, A.; Palee, S.; Arjinajarn, P.; Pompimon, W.; Chattipakorn, N. Pinocembrin reduces cardiac arrhythmia and infarct size in rats subjected to acute myocardial ischemia/reperfusion. Appl. Physiol. Nutr. Metab. 2015, 40, 1031-1037. [CrossRef] [PubMed]

143. Russo, A.; Cardile, V.; Sanchez, F.; Troncoso, N.; Vanella, A.; Garbarino, J.A. Chilean propolis: Antioxidant activity and antiprolif-erative action in human tumor cell lines. Life Sci. 2004, 76, 545-558. [CrossRef] [PubMed]

144. Korkina, L. Phenylpropanoids as naturally occurring antioxidants: From plant defense to human health. Cell. Mol. Biol. 2007, 53, 15-25. [PubMed]

145. da Silva Frozza, C.O.; Garcia, C.S.C.; Gambato, G.; de Souza, M.D.O.; Salvador, M.; Moura, S.; Padilha, F.F.; Seixas, F.K.; Collares, T.; Borsuk, S.; et al. Chemical characterization, antioxidant and cytotoxic activities of Brazilian red propolis. Food Chem. Toxicol. 2013, 52, 137-142. [CrossRef] [PubMed]

146. Jasprica, I.; Mornar, A.; Debeljak, Ž.; Smolčić-Bubalo, A.; Medić-Šarić, M.; Mayer, L.; Romić, Ž.; Bućan, K.; Balog, T.; Sobočanec, S.; et al. In vivo study of propolis supplementation effects on antioxidative status and red blood cells. J. Ethnopharmacol. 2007, 110, 548-554. [CrossRef] [PubMed]

147. Zhao, L.; Pu, L.; Wei, J.; Li, J.; Wu, J.; Xin, Z.; Gao, W.; Guo, C. Brazilian Green Propolis Improves Antioxidant Function in Patients with Type 2 Diabetes Mellitus. Int. J. Environ. Res. Public Health 2016, 13, 498. [CrossRef] [PubMed]

148. Mujica, V.; Orrego, R.; Fuentealba, R.; Leiva, E.; Zúñiga-Hernández, J. Propolis as an Adjuvant in the Healing of Human Diabetic Foot Wounds Receiving Care in the Diagnostic and Treatment Centre from the Regional Hospital of Talca. J. Diabetes Res. 2019, 2019, 2507578. [CrossRef]

149. Isla, M.I.; Moreno, M.I.N.; Sampietro, A.R.; Vattuone, M.A. Antioxidant activity of Argentine propolis extracts. J. Ethnopharmacol. 2001, 76, 165-170. [CrossRef]

150. Elnager, A.; Hassan, R.; Idris, Z.; Mustafa, Z.; Wan-Arfah, N.; Sulaiman, S.A.; Gan, S.H.; Abdullah, W.Z. Fibrinolytic Activity and Dose-Dependent Effect of Incubating Human Blood Clots in Caffeic Acid Phenethyl Ester: In Vitro Assays. BioMed Res. Int. 2015, 2015, 1-10. [CrossRef] 